\title{
EXHIBITIONS AND NOTICES.
}

\section{May 9, 1911.}

\section{E. G. B. Meade-Waldo, Esq., Vice-President, in the Chair.}

Mr. R. I. Pососк, F.R.S., F.L.S., Superintendent of the Gardens, exhibited some of the hair of the "puppy coat" of a Grey Seal (Halichorus grypus), which was caught at Barmouth, in Merionethshire, at the end of April. When received at the Gardens at the beginning of May this Seal was covered, with exception of the head and flippers, with longish woolly white hair, the last of which was moulted on May 7 th. Most authorities state that Grey Seals are born in the autumn, not later than about the middle of October, and that the puppy coat is shed from a month to six weeks later. Allowing six weeks for the retention of its puppy coat, this Welsh Grey Seal must have been born near the middle of March, a date in tolerably close agreement with the date, namely the end of February, given by Cneiff for the birth of these Seals in the Gulf of Bothnia. It is, therefore, quite clear that these Seals breed both in the early spring and the autumn.

Mr. E. G. Boulenger exhibited some living male specimens of the Midwife Toad (Alytes obstetricans) carrying the eggs. He also exhibited a number of the detached eggs to show the manner in which they were strung together.

Mr. A. E. Anderson exhibited a large number of photographs of the more important fossil mammals in the Department of Vertehrate Palæontology of the American Museum of Natural History, New York, showing the methods of mounting fossil skeletons. For comparison, a set of photographs was exhibited with the skeleton supports eliminated from view, thus adding to the pictorial value of pose in the specimens.

\section{PAPERS.}

33. An Investigation into the Validity of Müllerian and other forms of Mimicry, with special reference to the Islands of Bourbon, Mauritius, and Ceylon. By Neville Manders, Lieut.-Colonel, R.A.M.C., F.Z.S., F.E.S.

[Received May 8, 1911: Read May 9, 1911.]

Naturalists generally and the majority of entomologists are disposed to accept a broad view that mimicry is caused by 
natural selection, but beyond this some are not prepared to go. Others believe more or less implicitly in cryptic mimicry, either active or passive, and that peculiar form of it known as Batesian mimicry, that is, the resemblance for protection of a palatable to an unpalatable species. And there are others again who, believing in these, consider that Muillerian mimicry, that is, the resemblance of unpalatable species for mutual protection brought about by the tasting experiments of young reptiles and birds, plays a very large part, even an overwhelming one, in the production of mimicry.

The theories of the two great naturalists Bates and Müller have now been before us for a great number of years; but both, the latter more especially, base their claims to recognition on indirect evidence and not on experiments and investigation in the field. The exponents of these two theories maintain that though direct evidence is largely absent, yet on no other reasonable hypothesis can these remarkable cases of mimicry be explained. The opponents, on the other hand, hold the view that as direct evidence is possible though admittedly difficult to obtain, it ought to be produced before either theory can be admitted as proved, and until it is forthcoming they remain either actively hostile or passively sceptical. It was with the feeling that both the supporters of these theories and those opposed to them were equally desirous of reaching some finality in this vexed question, which has now been before them in one form or other for half a century - a question which, with its periodical exhibition of violent eruption and deceptive quiescence much resembles an Iceland geyser-that I have during the past five years devoted as much of my time as was practicable to the study of insectivorous birds and reptiles; and I have taken as my areas of investigation the islands of Bourbon, Mauritius, and Ceylon, because the question is less complicated on an island of small or moderate dimensions than on such an extensive area as Africa or South America.

Before I left England in 1908 I had the great advantage of being taken over the National Collection of Butterflies by Mr. Guy Marshall, who, with his unrivalled knowledge of the subject and persuasive powers, almost then and there made me throw in my lot with the supporters of the Müllerian theory, but in the midst of his arguments recollections of scenes in tropical jungles obtruded themselves, and I was left in an irritating condition of mingled belief and incredulity. A fairly extensive reading of the whole subject consequently did little to convince me, and my personal bearing towards both Batesian and Müllerian mimicry was that the verdict must be the unsatisfactory one of "not proven."

I propose taking each of the islands in turn, enumerating the reptiles and birds with their habits and distribution, directing attention to the more striking cases of mimicry, and endeavouring to ascertain on such data how far these theories are negatived or sustained. 


\section{Bourbon.}

Bourbon is a small circular island less than forty miles in diameter, lying some three hundred miles from the east coast of Madagascar. It has only twenty-two species of butterflies and certainly one case of mimicry, which is very striking and quite peculiar. It is that of a female Papilio (phorbanta) resembling a Euploea. The group to which this Papilio belongs is green in both sexes, but in this insect the female is dark brown and resembles more or less closely the brown Euploea (goudoti) occurring in the island. There is no occasion to go into details, as I have already brought them to the notice of the Entomological Society in its Proceedings and Transactions, 1908, and have figured both butterflies; but I may add that they are essentially insects of the littoral, common on one small portion of the coast, particularly in gardens on the outskirts of. St. Denis, but very rarely found above 1,500 feet or 2,000 feet. They are generally associated.

Bourbon has no lizards with the exception of one introduced species which is very rare. I was fortunate enough to find a specimen; and I should say, judging by somewhat similar Ceylon lizards, that in all probability butterflies would form part of its diet, but it is far too rare to have any marked effect on the butterfly population.

The following is a list of the insectivorous birds given to me by a resident naturalist, which, so far as my knowledge extends, is complete:-

1. The Sparrow. Passer domesticus.

2. The Mynah. Acridotheres tristis.

3. Zosterops (Malacirops) borbonica.

4. Zosterops hasitata.

5. Bec-Bec. Pratincola (Motacilla) sybilla.

6. Coq des bois. Trochocercus borbonicus.

7. The Wheat Swallow. Phedina borbonica.

8. The Little Grey-rumped Swiftlet. Collocalia francica.

9. Le Merle cuisinier. Lalage (Oxynotus) newtoni.

With regard to these, two, the Sparrow and Mynah, have been introduced; on the former I need make no remark, it has the same habits as its English relations. Two efforts have been made in the last hundred years to instal the Mynah, but without success, and this because it is considered a desirable morsel by the natives and is mercilessly trapped and consequently very scarce; I saw only one pair during my stay in the country.

Both species of Zosterops are very small birds, no bigger than the English wren, and are found either singly or in small family parties of five or six, flitting and creeping about the shrubs after the manner of our long-tailed tits; they feed on nectar and small insects. The Motacilla or Chat is of the same size and much the same colouring as the Whinchat, and quite possibly feeds 
on the smaller butterflies, but would scarcely tackle an insect considerably larger than our Swallowtail, but of this I have no evidence. I saw it frequently in the gorge leading up to Salazie and on the hills round St. Denis, but I saw nothing of it in the neighbourhood of the town.

The Flycatcher (Trochocercus borbonicus) is the same species as occurs in Mauritius ; it is said, on the authority of M. de Charmoy, to feed on diptera and by preference on mosquitoes. It is quite a small bird.

The Wheat Swallow (Phedina borbonica) has precisely the same habits as regards its food as the English species ; it appeared to me to be fairly plentiful. It also occurs in Mauritius.

The Little Grey-rumped Swiftlet (Collocalia francica) is the wellknown species that forms a nest of inspissated saliva. It occurs in Mauritius. It is quite a small bird, decidedly smaller than our Sand-Martin, and may occasionally snap up a small Lycænid.

Le Merle cuisinier, or Tui-tuit - Lalage (Oxynotus) newtoni. I am unable to say whether this bird is abundant or not, or whether it destroys butterflies. I did not come across it in Bourbon, so I am inclined to doubt its being particularly common. It has the same habits as the Mauritius Lalage rufiventer.

In the absence of any living bird it occurred to me that possibly the extinct Bourbon Starling might have been the prime factor in producing this case of mimicry, and I therefore wrote to my venerable friend Dr. Jacob de Cortimoy for information concerning it. He is now verging on his ninetieth year, and is probably the only one now living who has seen this bird alive; his letter is so interesting that I need make no apology for transcribing a portion of it.

"I have known the bird you ask me about since childhood, namely the Fregilupus varius (old writers called it $F$. capensis), which has in fact entirely disappeared ...... When I was a boy this bird lived in the forests of the interior of the island and never set foot nor wing in towns or inhabited places. It remained faithful to the forests where it was bred, which it enlivened with its clear notes. I used to hunt it then at an age when one is pitiless. I can see it now, a little larger than the white blackbird, with a white crest on the head in the case of the male, the wings a blackish grey on the upper surface, the beak and feet yellowish. By no means shy, it was not frightened even by the sound of firearms, and after a regular slaughter one went off with dozens of these poor victims in one's game-bag.

"After ten years spent in Paris I did not find a single one in the forests where formerly they flew about in flocks. All ruthlessly destroyed. I shall never forgive myself for the part, slight though it was, which I took in the matter. I lost my taste for sport and the best bag would not tempt me...... We will now consider the feeding habits of this bird. Having raised several in the aviary, I can risk talking about it though I never saw 
one feeding in the wild state. In my aviary its food consisted of bananas, potatoes, and choux-choux, Sechium edule (boiled). But when left to its own instincts, it must, like the other winged denizens of the forest, have eaten insects as is done by its companion in the forests, the Bourbon Blackbird (Hypsipetes olivaceus) *, and as is the habit of most fruit-eating birds."

This is a sad commentary on our boasted civilization, and I have only to add that not half a dozen skins are now in existence.

This bird cannot have been in any way the cause of this mimicry, as it inhabited the forest-covered hills in the interior of the island, where these butterflies do not occur.

Papilio phorbanta female was figured by Boisduval in 1833 and differs in no way from recent specimens. We may therefore infer that the factor or factors which primarily induced this change of colouring are still active; but as there is no reptile or any bird now living which attacks these butterflies as adults, it is difficult to accept this as an effect produced by them. And it would seem that the young of existing birds, with possibly one or two exceptions, would be too small and feeble to attack these large butterflies during their tasting experiments.

I now turn to the island of Mauritius, which lies some eighty miles to the north of Bourbon and which is visible from there on a clear day at certain seasons of the year.

\section{MaURITIUS.}

Mauritius has no arboreal lizards, and but one species of groundlizard, in appearance very like the English Sand-Lizard. It is confined to the coast, and is I believe somewhat uncommon. I found it in some numbers on the uninhabited islet of the Ile de la Passe at the entrance of Mahébourg harbour. It was quite tame, even confidential, and made no display of timidity in taking and eating a small piece of boiled potato presented to it on the end of a fork. We may, I presume, regard this lizard as an indiscriminate feeder !

My friend M. d'Emmerez de Charmoy, Director of the Port Louis Museum, a Mauritius gentleman who has an unrivalled knowledge of the fauna, and who has tracked, shot, skinned, dissected and mounted the whole of the splendid collection of Mauritius birds in the Port Louis Museum, has very kindly favoured me with the following list and notes on the insectivorous birds; it can be taken as complete, and I doubt whether any local fauna of a tropical island is so completely known as is this to M. de Charmoy.

I have added a few notes of my own in square brackets.

\section{Le Mangeur de Poule (Tinnunculus punctatus) [Cerchneis punctata].}

Feeds preferably on insects rather than on small birds.

\footnotetext{
* This bird occurs in Mauritius, but was not given to me by the Curator of the Museum as an insectivorous bird.
} 
I have many times discovered in their stomachs the remains of locusts, field-crickets, and also stick insects.

[This Kestrel is rather smaller than the English bird and, like it, is persecuted persistently. It may also feed on butterflies, but it is so rare that its influence can be little felt; it is entirely confined to the small portion of indigenous forest now remaining.]

2. Le Merle cuisinier (Oxynotus ferrugineus) [Lalage rufiventer.]

Is essentially insectivorous; I have seen these birds catching Mantis religiosa and I have found in their stomachs Scarabæi (Cratopus) and fragments of moths' wings.

[This bird of late years has become exceedingly rare and is verging on extinction. On my telling M. de Charmoy that I had seen a pair in the forest, he congratulated me with as much fervour as if I had seen a Dodo!]

3. L’Oiseau Banane (Foudia erythrocephala).

Frequents very persistently bananas when in flower, and captures the minute insects which are attracted by the honey of these flowers; lives also on the petals of flowers and on small lepidopterous larvæ. [M. de Charmoy considers from his dissections that this bird is incorrectly placed in this genus, which is essentially a grain-feeding one.]

4. All these species are indigenous and so also are the two species of Zosterops, Z. mauritiana and Z. chloronota, which live almost entirely on the larvæ of lepidoptera. I am unable to give the names of the kinds they capture, but no doubt they take any kind of caterpillar.

5. Le Coq des bois (Muscipeta borbonica) [Trochocercus borboni$c u s]$. Also indigenous; is an inhabitant of the forests and is found also along river-courses; it chases diptera by preference and particularly mosquitoes.

6. Le Boulbul (Pycnonotus jocosus) was introduced in 1892 by M. Gabriel Reynard and is now to be found everywhere. It is certainly to be found in great numbers, being often a plague. It consumes the best fruits and vegetables and the blossoms of fruit trees. I have often seen it hunting for moths, especially for Ophiusidæ, and in the fields of wild indigo it captures Lycænidæ. [The most common butterfly in these fields is Lampides bretica.]

7. Le Martin (Acridotheres tristis) was introduced from the Coromandel coast by M. Boucher des Friyes, and by Pierre à Mainard (?) into Réunion, to destroy the crickets which ravaged the islands in 1759 . It is found in great numbers in newly tilled fields hunting after all sorts of insects, and especially after the eggs of crickets.

The Fringillidæ cannot be considered insect hunters though they catch one on the wing when they come across it. They Proc, Zool. Soc.-1911, No. XLIX. 
have not the slightest share in the reduction of local species (of insects).

There are thirty species of butterflies, but with the exception of Hypolimnas misippus and Danais chrysippus there is no such well marked case of mimicry as that of the Euploea and Papilio in Bourbon.

Professor Poulton has however thrown out the suggestion that the female Papilio manlius, though green, is approaching Euplcea euphon, as it is of a distinctly brownish green tint compared for instance with the Madagascar P. epiphorbas. Mr. Trimen also considers that Danais (Amauris) phaedon and the Euploa mimic each other to a certain extent. Instances of seasonal dimorphism (cryptic defence) are however numerous.

The evidence I have collected does not seem to justify the contention that the above instances of mimicry are due to the depredations of old birds or to the experimental tasting of young: ones. Though no doubt experimental tasting of insects generally takes place, it would appear that the birds are of such a character that butterflies would not be attacked except to the smallest extent.

\section{Ceylon.}

I now turn to the island of Ceylon. If the problem we are considering has so far been simple owing to the small size of the islands dealt with and their very limited fauna, it is by no means so in Ceylon, which is far larger, being about two-thirds the size of Ireland, with a wonderful diversity of hill and plain and equal diversity of climate. Its general characteristics are too well known to require repetition, and there are two hundred and sixty species of butterflies.

Mimicry among Ceylon Butterfies.

Mimicry is by no means uncommon among Ceylon butterflies and the following will serve as examples of it.

Мiмic.

Hypolimnas bolina 오.

". misippus $q$.

Elymnias fraterna 우.

Argynnis hyperbius ㅇ.

Pareronia ceylonica + .

Prioneris sita.

Papilio clytia race

lankeswara ơ 9 .

Papilio clytia form dissimilis.

Papilio polytes 9 .
Model.

Eruploea (several species).

Danais chrysippus.

$"$ plexippus.

", aglea.

Delias encharis,

Euploca (several species).

Danais aglea (and allies).

Papilio aristolochice.

Papilio hector.

And the Muillerian combination of the three Euploas, core, coreta, and kilugii.

Euploea coreta and E. core, as a reference to Mr. Moulton's plate 
in Trans. Ent. Soc. Lond. for 1908 will show, are extremely alike, yet under certain circumstances I can recognize them when on the wing without great difficulty. When herded together in shady jungle, as is their frequent custom, it is impossible to differentiate them; but when flying singly over an open space, the former appears a blacker and broader insect with a rather more flapping flight, by which I can usually distinguish it from $E$. core.

The resemblance between Danais chrysippus and Hypolimnas misippus $q$ is well known, and I have often found them mixed together in local collections, but on the wing under ordinary circumstances differential diagnosis is by no means impracticable: the female of the latter is almost invariably seen flying close to the ground selecting favourable situations for oviposition, and her method of flight, difficult to describe, differs from that of D. chrysippus, which oviposits on a shrub some four or five feet in height; when not thus engaged the two are undoubtedly difficult to distinguish at about ten yards distance, and it is curious how often the male of $H$. misippus mistakes D. chrysippus for a female of its own species. Prioneris sita can at once be distinguished from Delias eucharis by its rapid darting flight.

A case of resemblance, though not always stated to be one of mimicry, is that of Argynnis hyperbius female and Danais plexippus or D. chrysippus. This was remarked on by Butler so long. ago as 1884 and has been repeatedly noticed since, particularly by Longstaff and Bainbrigge Fletcher. The resemblance is, however, entirely accidental, as their habitat in S. India and Ceylon clearly shows. Broadly speaking, if observed above 4000 feet, it will assuredly be A. hyperbius, if on the littoral and up to about 4000 feet, almost certainly $D$. plexippus; it is only on the confines of each other's territory that they in any way come in contact and where an error can be made. Cethosia nietneri, Danais ceylonica, and Papilio clytia (dissimilis) fly in the same localities, that is, in jungle where the light is very flickering. It is not only very difficult to distinguish them apart, but they are quite difficult to see, as their black and white marking tends to make them invisible. They also frequent the outskirts of jungle and even more open country, and here they are quite easy to distinguish, particularly $P$. clytia (dissimilis), which is a larger and much yellower butterfly.

Mr. T. Bell considers Cethosia to be an unpalatable genus owing to the nauseous juices and leathery bodies of the species. Euripus consimilis very closely resembles a Danaid in both sexes, and would be considered an undoubted case of either Batesian or Müllerian mimicry: it is not a Ceylon butterfly, and I first made its acquaintance in the Nilgiris ; by its lofty sailing flight, particularly in the female, I recognized it at a glance from a Danaid, which rarely or never ascends more than about ten feet from the ground.

It is more in their peculiar manner of flight rather than in any difference of colouring that model and mimic can as a rule 
be distinguished; when at rest the difficulty is considerably greater, and I would draw particular attention how not infrequently butterflies of a similar pattern on the under surface of their wings chose the same resting places, and often the same bush or branch on which to settle for the night. The following two notes indicate this.

"Colombo, July 1909. I observed at sunset sixteen Telchinia violce and some Danais chrysippus with their wings closed, at rest on a leafless bush; they exactly resembled withered leaves, and it was exceeding difficult at ten measured paces to distinguish the species, at about twenty paces it was very difficult to recognize them as butterflies at all, and at thirty paces they were practically invisible."

"Kullar, Nilgiris, 12.4.1910. In a grove of Areca palms Euploca coreta, E. core, Danais limniace and D. septentrionis simply swarmed, they were in hundreds and hung in festoons from the palms. Though many of each kind were on each leaf, they usually kept together. It was deep shade, and the Euplœas seemed to match the decayed vegetation and the Danaids the green leaves. There were also many Danais plexippus but no other butterflies."

With regard to the above quoted instances, Mr. R. C. Punnett, after a study of them for about six weeks, writes: "With the exception of Argynnis hyperbius and Prioneris sita, I have had frequent opportunities of observing all these cases, and in every one it has appeared to me that the resemblance is far less striking when the insects are seen alive than when they are exhibited pinned out in the orthodox way on cork. I have found that with very little experience the eye comes to distinguish the mimic from the model without hesitation. As a rule it is in the mode of flight that they differ from one another ...... My impressions of all these so-called cases of mimicry which I have been able to see, is that the resemblances are certainly not sufficiently close to deceive the eye of a civilized man with a little experience of them. For that reason I am inclined to doubt whether they would systematically deceive an enemy brought up among them, whose means of earning a livelihood depended largely upon the readiness with which he could distinguish between mimic and model. I do not wish to deny that in some cases, and upon occasion, the resemblance may be of service."

All local entomologists would endorse the above remarks, but there is this to be said, that Mr. Punnett was aware of these cases of mimicry before he arrived in Ceylon, and was on the look out for them; if he had been totally ignorant of them, it would have taken him some time before he recognized the phenomenon, but having once done so, he would no doubt have had no further difficulty.

The detection of certain cases of mimicry would appear to be greater in some countries than in Ceylon. Colonel Bingham, writing of the Papilio clytia group, says: "They have nearly all a wonderful resemblance to forms of Euploea and Danais, and it 
requires a quick eye and some experience to discriminate between Euploea and Papilio clytic race panope and between Danais limniace and the dissimilis form of $P$. clytia, especially when on the wing." In reply to a query of mine on this point Mr. W. F. H. Rosenberg writes:- "London, August 29th, 1910. During my travels in Colombia and Ecuador I found that mimicking species did frequent the same places as their models. For instance, the Dismorphias (Pierines) which mimic certain groups of Ithomiine butterflies, such as Ithomia zelica, were seen flying in clearings in woods etc., in company with the Ithomias. It is curious to note, however, that there is a slight difference, difficult to describe, in the mode of flight of the two groups, so much so that a trained collector would rarely mistake one for the other. Again, the S. American Acræines of the genus Actinote, which settle in groups on damp patches of sand, have their mimics in the shape of Nymphalines of the genus Eresia. But while the Actinotes will allow themselves to be picked up with the fingers, the Eresias always fly up on the approach of danger."

The Rev. St. Aubyn Rogers also, in his well known paper on East African butterflies, mentions how often at first he was deceived by model and mimic, but how after a short acquaintance he readily recognized them.

But confining myself to Ceylon, the ease with which every case of mimicry occurring there can usually be detected, causes me to be in sympathy with those who consider that this constitutes a great difficulty in the acceptance both of Batesian and Miillerian mimicry. Both reptiles and birds are well represented, and in order to afford a complete study of the fauna I propose taking them in order, first dealing with the reptiles. I can scarcely hope not to have overlooked some species, but I trust there is no serious errol.

\section{The Lizards of Ceylon.}

Five families are represented; namely Geckonidæ, Varanidæ, Scincidæ, Lacertidæ, and Agamidæ. The first three of these are almost unquestionably of no account in our enquiry. The Geckonidæ are mostly nocturnal with but one diurnal species, Gonatodes kandianus, common in houses at Kandy and confined to that part of the island. The Geckos I have observed feeding. at night were quite indiscriminate in their captures. Of the Varanidæ, two species are large carnivorous lizards, commonly called iguanas, frequently attaining a length of three or even four feet. One species when young ascends trees, and $\mathrm{Mr}$. Rosenberg has seen a Mexican species eating butterflies.

The Scincidre has four genera, Acontias, Chalcidoseps, Lygosoma, and Mabuia. The first has four species with limbs rudimentary or absent; in appearance they are very like our slowworms but smaller. One species, A. burtoni, is usually found under stones, and the others, so far as I have been able to ascertain, inhabit similar situations. They appear to feed on 
small worms. Chalcidoseps has but one species, C. thwaitesii, a small creature about two inches long with very short limbs. It is not represented in the Colombo Museum collection, and I am unacquainted with it. Lygosoma has three species, one found in the hills, the other two common in the low country. Their forelegs are very feebly developed, in fact almost rudimentary, and judging by their general appearance they probably have the same habits as the next genus, Mabuia, which contains two species, one of which is rather rare; the other, M.carinaia, is the well known Brahminy Scink, which so far as my experience goes feeds almost entirely on ants, I have invariably failed to get it to feed on butterflies.

The family Lacertidx has but one genus, Cabreta, containing a single species leschencultii, very small and rare, found only at Mullative in the arid north-western district.

The Agamidæ has five genera, but three are represented by a single species in each. Otocryptis bivittata, a very small creature, confined apparently to the wet districts up to 2,000 feet: I have no personal acquaintance with it. Cophotis zeylanica, also small and found only in the hills : in captivity it feeds readily on flies, which it captures after the well known manner of the chameleon. Lyriocephalus scutatus, a magnificent creature found only in the outer hill-ranges, where the climate is hot and moist. My friend Mr. Alers Hankey, who has kept these species both in captivity and at large in his garden, informs me that they feed on "almost anything - moths, flies, beetles, grasshoppers, worms, and even boiled rice." We may conclude that their taste in butterflies, which they in all probability eat somewhat extensively, is impartial.

The genus Ceratophora has three species only, one of which I know, $C$. stoddartii, found only in the bigher ranges. It feeds on worms and positively declined butterflies when in captivity.

The genus Calotes has seven species, three of which are somewhat rare; these I do not know nor one other, C. mystaceus. Two, $C$. ophiomachus and C.versicolor, are extremely abundant from the coast to about 3,000 feet, thence upwards nigrilabris takes their place and is likewise very common. All members of the genus have probably the same habits and are undoubtedly highly destructive to insect life. In fact I have little hesitation in saying that they are the greatest enemies that butterflies have to contend against, and when in Nuwara Eliya in 1909 I should have had no great difficulty in making a fair collection of butterflies mutilated by them. The injuries were of all kinds, but mostly a semi-circular piece, the size and shape of the lizard's jaw, had been taken out of the hind wing. These mutilated butterflies indicated no discrimination on the part of their enemy; perhaps Argynnis hyperbius was the most frequent victim. My experiments, though not so complete as might be wished, show that these lizards exercise no partiality; but the butterflies experimented with are those commonly found in the gardens at Colombo, 
where Calotes is abundant, and almost all those which occur at Nuwara Eliya, the fauna of which is very poor.

\section{Experiments with Lizards in Colombo.}

The two species of reptiles experimented on belonged to the genus Calotes ( $C$. ophiomachus and $C$. versicolor), or blood-sucking lizards as they are commonly called. In appearance and habits they are far more like Chameleons than ordinary Sand-Lizards, and like them have the faculty of changing colour and assuming on occasions brilliant scarlet, yellow and green, particularly about the head; but on the other hand they are very quick in their movements and can run with considerable speed. They are usually to be found sitting on walls and palings, clinging to the stems of the longer grasses, and frequently lying in wait for their prey behind the umbels of flowering shrubs, where their gaudy colours help to deceive visiting insects. In such positions they will wait motionless for hours on the chance of prey coming within reach. But as I was unable to devote a whole day for such prolonged investigations, I adopted the following method as being the nearest approach to natural circumstances. I attached a defunct or moribund butterfly by a long line of fine silk to a fishing-rod, and thus succeeded with the help of the wind in bringing the fly within reach of the reptile. The following were the results from the end of November to the end of December 1908 , with the notes I made at the time.

November 24. A male Papilio polytes was waved over a green Calotes ophiomachus which was clinging to some grass. The lizard became slightly excited and made a grab at the insect, biting out a piece of the fore wing and immediately eating it; a second time it bit a piece out of the hind wing including the tail; the insect if alive would certainly have escaped on both occasions. Finally it seized it by the head and ate the remainder.

November 30. A female Papilio polytes of the black and white variety offered in the same way to another Calotes. This lizard, which was evidently hungry, became excited when he saw the butterfly, and made a grab at it and bit out a piece of the fore wing: which it promptly began to eat; the butterfly would have escaped. While this "fishing" was going on, a male butterfly attracted by the female flew quite close to the lizard, which made a dart at it and tore away a piece of its wing, and the butterfly flew off. A lizard grabs at any part of the butterfly that comes within reach, and as the grass sways when it moves it is quite a chance what part is seized; the habits of Calotes therefore negative any theory of so-called directing marks so far as they are concerned.

November 25. The wings of the black and white variety of $P$. polytes are quite common in the garden, and I am quite sure the Calotes devour great numbers of them. I saw $C$. versicolor with a live one in its mouth; on this occasion it was holding the 
insect by the fore wing-when it saw me it ran to a tree, and I fancy dropped the insect which, as I could not find it, probably flew away.

December 4. Saw C. versicolor seize Delias eucharis on the wing. On this occasion the lizard was in the foliage at the top of a bush, and sprang out and captured the butterfly as it flew past.

December 6. Euploca core was eagerly seized, held in the mouth for a long time and then eaten.

December 7. Telchinia viole was eagerly seized by the body and devoured.

December 9. Two Danais chrysippus taken one after the other by a green Calotes ophiomachus. It watched the butterfly, seized it by the body, and ate the whole of it after holding it in its mouth for some minutes.

December 18. Papilio (Menelaides) hector seized as soon as seen, held in the mouth for some time and eaten slowly. The lizard seemed very puzzled at the dryness of its meal as the butterfly had been dead five days, but finally ate it all.

December 20. C. ophiomachus ate a male Papilio polytes.

December 30. Saw Terias hecabe captured by Calotes versicolor.

During these two months butterflies and other insects were very numerous owing to the rain at the break of the N.E. monsoon. The tall Mauritius grass in the garden was a place of refuge for the butterflies during the heavy rain, and numbers of them could be seen any morning sunning themselves and sitting with expanded wings halfway up the grass stems. $P$. polytes and $P$. demoleus were particularly numerous and several had pieces taken out of their wings, no doubt by lizards. It was an interesting fact that so long as the butterflies remained perfectly still, they were entirely unnoticed by the lizards, though they might be in close proximity to them. Both these butterflies rest throughout the night with wings widely expanded.

\section{Experiments with Lizards in Nuwara Eliya, 6,200 ft.}

Three species were experimented on, Calotes nigrilabris, Cophotis zeylanica, and Ceratophora stoddartii. All three are peculiar to Ceylon and confined to the hill-districts. C. nigrilabris is about a foot in length including the tail, and is brilliant emerald green with a black bar across the lips. It has the same habits as C. versicolor and $C$. ophiomachus but is much tamer ; in fact it is not at all difficult to capture with the hand as it rests on a bush.

\section{Calotes nigrilabris.}

3.3.09. Ate a Terias hecabe greedily, and another shortly after.

3.3.09. The same lizard ate another $T$. hecabe, and another made frantic grabs at $E$. core, dangled as usual at the end of a 
string; when eventually I allowed it to take it, it ate it readily. The same lizard ate $T$. hecabe.

7.3.09. Another lizard ran out from its bush and caught Terias libythea. A Papilio aristolochice, a very scarce species in N'Eliya, caused great excitement in a male and female on the same bush; they rushed out to capture it, then drew back apparently frightened at its size and at length would have nothing to do with it. Offered to another it was seized by the fore wing and a part only eaten, the reason being that it was frightened of me. Offered again to the first pair they took no notice of it, but one made a jump of quite six inches and snapped up a fly which had settled on a leaf. This shows that they were hungry at the time.

15.3.09. A fresh Appias galene $q$ readily taken, but not so eagerly as by another which had recently changed its skin and to which some of the slough was clinging. This was very hungry and made quite a respectable jump at $A$. galene ${ }^{*}$, which it caught round the body. Immediately afterwards it devoured Catopsilia pomona.

15.3.09. Offered Papilio (Menelaides) hector to a remarkably fine lizard, which caught it by the base of the hind wings ; these it ate very slowly and dropped the rest, no doubt because it was too dry. The same thing happened with Telchinia violce and another lizard. These two butterflies do not occur in N'Eliya.

16.3.09. A female moth, Spilosoma melanopsis, Fam. Arctiidæ, with remarkably large brilliant crimson body and pink hind wings, the dull fore wings being removed, was at once taken by a lizard, which ran some distance after it. It proved a very considerable mouthful which took quite half an hour to get rid of.

During March, April, and May I noticed a very considerable number of butterflies, more particularly Argynnis hyperbius, with pieces taken out of their wings, usually the posterior portion of the secondaries. I have no doubt that almost all these injuries were caused by this species of Calotes which is very numerous at N'Eliya. I might almost say there is a specimen on every bush.

19.3.09. A Euploea core of proved very attractive; a halfgrown lizard ran more than a yard out of the hedge and seized it by the head as it lay on the ground. With the same species a large male made a dart at Danais fumata attached as usual to a line of silk, caught it by the hind wing and devoured the whole of it. A smaller individual seated on a bush of salvia became highly excited by Polyommatus botica with its wings closed, and ran all over the plant after it, eventually catching it by the body; immediately afterwards it ate three Terias hecabe, one after the other.

24.4.09. A female lizard, and one I have frequently experimented on, ran from its hiding place and caught Pyrameis cardui by the head after considering for a moment its cryptic underside. Another scrambled over its bush in the usual way and seized Lethe daretis $q$ by the hind wing.

These lizards were very tenacious in their grasp : as a rule, after 
capturing their prey, they hold it quietly in the mouth for some time, but if it struggles they immediately begin eating it. A renewal of a struggle leads to the same thing.

\section{Cophotis zeylanica.}

This lizard is found only in the hill tracts of Ceylon, and is most frequently found resting on tree-trunks in shady places. It has considerable power of adapting its colouring to its surroundings, but not to the same extent as the Chameleon. It is almost five inches long including the tail, which is usually two or three inches. It is extremely sluggish in its movements, depending entirely on its cryptic colouring to escape observation. It is quite harmless and can easily be taken in the fingers. It eats flies readily in captivity, but all my efforts, both with specimens at large and in captivity, to induce them to eat butterflies resulted in failure, even those with their wings entirely removed seemed only to frighten them.

\section{The Horned Lizard. Ceratophora stoddartii.}

This interesting reptile is also peculiar to the island, entirely confined to the hills, and I do not think it occurs below 5000 feet. It varies in colour from a vivid green with black bands (three only seen) to a uniform brown. It has the faculty of changing its colour according to the nature of its environment. Only once have I found it otherwise than on a tree-trunk in deep shade, where butterflies very rarely penetrate. All attempts to make it eat butterflies in the wild state failed, and the following is a note on a captured specimen:-".13.4.09. Put numerous flies in its cage, there appeared to be a diminution the following morning. Put Terias hecabe and Pyrameis cardui alive into its cage. It did not notice the latter as it rested with closed wings on the gravel, though within three inches of it; but when it moved its fore wings up and down - not in and out-it was on the alert and crept up to it, but before it had made up its cautious mind to attack, the butterfly flew off, hitting it on the snout in so doing, which utterly disconcerted it." I may say that about the only butterfly in the upper hill district which frequents shady places is Lethe daretis. Mycalesis and Yphthima do not extend so high. The chance of a meal off a butterfly is therefore remote.

Dr. Willey informs me that its natural food is small worms.

It would seem then that those who assume that reptiles take no part in the production of Batesian or Müllerian mimicry are correct, though further experiments are required.

\section{The Insectivorous Birds of Ceylon.}

A few introductory remarks are needed before dealing with the insectivorous birds. Speaking generally the Mimicrists, if I may use the term, maintain that birds do eat butterflies largely; the Anti-Mimicrists that they do not. The evidence of the latter is 
necessarily negative, and we must therefore try to find some reasonable standard by which we can judge whether a particular bird is a butterfly eater or not. We shall not be far wrong if we employ the criteria accepted by Mr. Guy Marshall in his paper "Birds as a factor in the production of Mimetic Resemblances among Butterflies" (Trans. Ent. Soc. Lond. 1909), only in this case in a contrary sense. Speaking of the want of real evidence on the part of the Anti-Mimicrists, he says:-_."When a naturalist who has spent some time in the tropies expresses a decided opinion to the effect that birds do not normally eat butterflies, because he has never observed them doing so, it is incumbent on us, before accepting his evidence as having any real scientific value, to satisfy ourselves that he has made a systematic and thorough investigation of the subject, and that his views are not based merely on casual and inadequate observations. For in a matter of this kind there is grave danger that absence of evidence may be due simply to lack of observation. If a collector maintains that birds do not eat butterflies, we are justified in asking him for a full list (italics mine) of the other insects which he has seen captured by birds. And I venture to think that a closer inquiry of this kind would reveal the fact that most of the negative evidence which has been brought up against the Selectionist interpretation of mimicry is really of little worth."

Passing over the obvious reply that as it was the Selectionists who first asserted that birds ate butterflies, it is their duty to prove it if they wish their theory accepted, it would appear that Mr. Marshall does not consider it necessary for an observer to be very accurate as to the species captured before attributing butterfly-catching propensities to certain birds.

In the case of the Redstart we read that "They take flies, gnats, small butterflies, and all sorts of small two- and four-winged insects, partly on the wing and partly at rest" ; and again. "It feeds on flies, gnats, small butterflies, and various other kinds of small coleopterous and other insects, caterpillars, etc." Now if such evidence is accepted, namely, that the Redstart eats butterflies, without the necessity of naming the individual species captured (though it might well be suggested that these small butterflies were really small moths), it would appear only just that when such an authority as Legge states that the food of the large Indian Cuckoo-Shrike consists of "caterpillars, grasshoppers and various other kinds of coleopterous insects " without mention of butterflies, that such should be regarded as sufficient evidence that butterflies are not destroyed by it in sufficient numbers to cause any form of mimicry. But, on the other hand, when we read of a bird feeding "on beetles and the many larger members of the insect kingdom which affect Ceylon forests," it is quite possible that such a one would produce a struggle for existence among butterfies. It is only by adopting some such standard as this, faulty though it may be, that we are likely to come to any conclusion. As to the actual observation of insects captured by birds, no one who has not 
experienced it can form an idea of its difficulty. Let any one who would appreciate it, watch a blackbird or thrush in his own garden, and even with the best field-glasses he will be unable in the great majority of cases to name the species of insect caught, or more frequently than not the order to which it belongs. In the tropics the difficulties are increased a hundredfold : fortunately in the case of butterflies the task is lighter, and it is often easy to name the species owing to the habit some birds have of holding the insect in the bill for a few moments before swallowing it, and the lengthy time it takes others either to tear off the wings after the manner of Shrikes, or beat them off against the ground as is the custom of the Robin family. Bee-eater's and Paradise Flycatchers nip off the wings close to the body as neatly as if done by a pair of scissors.

A certain number of birds are migrants, such as the Cuckoo and Swallow, which pass a portion of the year in Ceylon and the remainder in northern latitudes; such birds, as pointed out by Mr. Marshall, would have to learn the distastefulness or otherwise of the butterflies that inhabit such dissimilar countries, and their influence on the butterfly population of both areas would have to be taken into consideration. These are, however, few in number compared with the partial migrants, which move from one part of the Oriental region to another; and the butterflies there being of the same character, the lessons they have learnt in one part of their distribution are valuable to them in another. A great many of the resident insectivorous birds move in an irregular manner from one part of the island to another according as their food supply varies, and as this consists of insects alone it is largely dependent on the rainfall. Such a movement cannot be strictly termed a migration and may be a few miles only; for instance, the rainfall in Colombo is about eighty inches, twenty miles off it is nearly two hundred; when there is a comparative paucity of insect life at Colombo the birds, or rather some of them, find plentiful sustenance by moving a few miles inland. Some birds again, such as the Robins, remain in and about the houses and gardens year after year, and others, such as the Green Beeeater, are never found in the wet portion of the island.

It is this slight to and fro movement which makes me sceptical of any insectivorous bird in Ceylon, and probably in any tropical island, being ever really hard up for food.

Mr. Marshall quotes Dr. Franz Doflein as writing: "From the observations which I made in the jungles of Ceylon, it is quite incomprehensible to me how naturalists who have spent years and tens of years in the tropics can deny the fact" [that butterflies are frequently attacked by birds]. I had very little doubt when I read this passage that Dr. Doflein was speaking of the north of the island, and his recorded observations confirm this; I should, however, be very surprised if he could say the same of the whole island, more particularly the hill districts. One point to which I wish more particularly to draw attention, is his suggested immunity from attack of the magnificent Ornithoptera darsius, 
attention being drawn by him to "its slow, lazy and almost unwieldy flight," the characteristics of an unpalatable butterfly. It does not occur or very rarely in the north of the island, where a bird, the Paradise Flycatcher, is very abundant, but at Kandy, to which place every visitor goes, and where possibly Dr. Doflein made his observation, the butterfly is very common and the bird rare, though I have seen it. But it so happens that at the foot of the Nilgiris, both bird and butterfly inhabit the same district and the former is an inveterate enemy of the latter, it eats numbers of them by nipping off the wings and swallowing the body. The slow, lazy flight may possibly advertise its unpalatability to some birds, but it makes it the easier victim to the Paradise Flycatcher, which in my opinion is the greatest enemy butterflies have in this part of the world.

I have always experienced considerable difficulty in understanding how a distasteful butterfly has acquired a slow sailing flight*. It is easy to see how swift flight could be brought about by natural selection, but the converse is not so clear. Presumably Euplœas, Danaines, etc., have always been distasteful on account of the poisonous or nauseous nature of the food-plants, and those of slower flight, as in the case of the palatable kinds, would naturally be first captured, and we can understand how a race of quicklyflying evil-tasting butterflies would be evolved by natural selection. But if quick flight is of assistance in enabling a tasty butterfly to escape capture, I find it difficult to believe that a nasty one, with equal powers of flight, would not be equally benefited. And if this be so, slow flight for the purpose of advertising unsaleable goods seems unnecessary and the method by which it has been evolved very obscure.

When we come to study fast-flying butterflies in their native haunts, we find in every case a different rate of flight according to the hour and weather. If it is a cloudy morning they fly much slower than they do in hot bright sunshine; the majority fly their fastest after 10 A.м. till 3 P.м., often resting between 12 and 2. But in the early morning and late afternoon, these same butterflies can often be captured with the greatest ease, as at this time they are usually feeding. This is the case with the rapidly flying Teracolus (fausta, danae, \&c.) and many Papilios, and this may account for the different opinion Dr. Doflein and I hold regarding $P$. hector and $P$. polytes. He considers them to be of swift flight, and so no doubt they are in the middle of the day, and particularly when flying over bare ground from one patch of cultivation to another; but on a dull day or early in the morning or evening they are particularly easy to eatch. If Dr. Doflein is correct we have here an instance of a Mïllerian combination of

* Mr. Marshall speaks of " the acquisition of unpalatability," by which I presume he means that a slightly nauseous butterfly has become more so by a process of evolution, and this has been accompanied by an increasingly slower flight. There is no proof, so far as I know, that a Euploea for instance has undergone any such process, and the assumption appears to be entirely theoretical. 
unpalatable butterflies adopting or having a naturally quick manner of flight which enables them more or less successfully to avoid the tasting experiments of young birds. I mention this in order to show the difficulties that beset us even in the field, and how two observers may form a diametrically opposite opinion on apparently such a simple matter as the flight of a butterfly. Dr. Longstaff is no doubt correct in saying that $P$. polytes has a quicker flight than $P$. hector.

This varying velocity of flight makes me somewhat sceptical that swiftness has been evolved in order to escape capture, as an enemy by selecting the opportune moment can effect the seizure of a fast-flying butterfly as easily as one of slow and laborious flight. Those foes of butterflies, the Bee-eaters, feed during the hot hours of the day, and Drongos in the morning, late afternoon, and often after sunset.

Many butterflies are conspicuous under one set of conditions and the reverse in another, even at the same time of the day. Telchinia violce is said to belong to the most distasteful group of butterflies. Its flight is slow and deliberate, and it is very conspicuous when flying over a grass field; its bright brick-red colour forms a strong contrast against the green, and it thus has the characteristics of an inedible insect. In the blazing dazzling sunshine on the dried-up plains of India its colour so matches the soil that it is decidedly difficult to see, particularly the female which is almost invisible. Its under surface matches admirably the dried-up leaves of the bush on which it frequently takes up its position for the night, and under these circumstances it has all the characteristics of an edible insect. On a day in March this butterfly was flying over the green gardens of Colombo, and three days afterwards I met it at Trichinopoly, with a shade temperature of $104^{\circ}$, dazzling sunshine, and scarcely a blade of grass to be seen. It will probably be held by Selectionists that in certain cases such as in extremely dry weather, even an inedible butterfly requires concealment and that conspicuousness is beneficial to it as advertising the worthlessness of its goods in the wet season, when insects are abundant. I have given my reasons for believing that in tropical islands there is no real scarcity of insect life that cannot be made good by birds. It may also be argued that its invisibility one moment and conspicuousness the next may be of advantage to it, but if this be so, it is difficult to understand why such an extremely distasteful insect as an Acrcea is held to be, should be obliged to pass through such a complicated process of evolution.

In compiling the following list of birds, I have followed Oates and Blanford, as their nomenclature is more modern than that of Legge; where not otherwise indicated, the notes in inverted commas are quotations from Legge.

Captain Legge spent eight years in Ceylon, and those who were there with him, now few in number, have a clear recollection of his knowledge, zeal, and painstaking industry. 
Fam. Crate r O P I D

Subfam. Crateropinæ. (The Babblers.)

"All feed on the ground like thrushes. They ... probably derive no portion of their food directly from trees, the fruit they occasionally eat being picked off the ground as they forage for insects." (Oates.)

1. The Southern Indian Babbler. Crateropus striatus.

"Its food is entirely insectivorous, and is mostly taken by scratching among leaves and débris on the ground."

2. The Ceylonese Babbler. C.rufescens. Indigenous.

"I found the stomachs of several examples killed in the month of August to contain portions of a large black beetle which was affecting the jungle in large numbers at the time."

3. The Ashy-headed Babbler. C. cinereifrons. Indigenous.

"Delights in exploring the mossy recesses of fallen trunks, in which humid spots it finds an abundance of caterpillars, bugs, hemiptera, and coleopterous insects."

4. The Ceylonese Scimitar Babbler. Pomatorhinus melanurus. Indigenous.

"Goes about in small companies searching for its insect food on low branches or clinging woodpecker fashion to the trunks or large branches, about which it jumps and twists itself with considerable agility."

\section{Subfam. Timelin ж.}

5. The Small White-throated Babbler. Dumetia albigularis.

"Its food consists of the larvæ of various insects and minute coleoptera."

6. The Ceylon Yellow-eyed Babbler. Pyctorhis nasalis. Indigenous.

"I have always found its food to consist of small coleoptera and various minute insects."

7. The Brown-capped Babbler. Pellerneum fuscicapillum. Indigenous.

"It feeds on the ground in dense thickets, picking up beetles and insects from amongst decaying herbage; it rarely shows itself in the open."

8. The Black-fronted Babbler. Rhopocichla nigrifrons. Indigenous.

"This modest but active bird frequents underwood, thickets and tangled jungle..... subsisting entirely on various insects and their larvæ.'

There is no indication among the Ceylon Babblers of any 
butterfly-eating propensity, but Mr. Frank Finn experimented with an Indian species (Crateropus canorus), and came to the conclusion that they distinguished in time between a tasty and distasteful butterfly. The note I made at the time I studied his experiments is as follows :- It is evident that they had no notion at first as to what was palatable and what was unpalatable, but as the experiments proceeded they learnt gradually to discriminate ..... I conclude that as these birds with one exception were adult when captured, they could not have undertaken tasting experiments when young, otherwise they would have recognized a distasteful species.

\section{Subfam. Brachy Pteryginæ.}

9. The Indian Blue-Chat. Larvivora brunnea. A migrant.

"Appears to feed entirely on the ground." (Oates.)

10. The Ceylon Arrenga. Arrenga blighi. Indigenous.

"The food consists of various insects and in the stomach of my specimen I detected the bones of a frog." Mr. Oswin Wickwar tells me that he found a species of snake, Aspidura sp., quite four inches long in the stomach of the bird shot by him.

11. The Ceylon Short-wing. Elaphrornis palliseri. Indigenous.

" Found in thick brushwood feeding on the ground." (Oates.)

"It feeds on ants and other minute insects and to some extent on small seeds."

12. The Indian White-eye. Zosterops palpebrosa.

13. The Ceylon White-eye. Zosterops ceylonensis.

These species have the same habits as those in Bourbon and Mauritius.

\section{Subfam. Liotrichinæ.}

14. The Fairy Blue-bird. Irena puella.

"It feeds principally on fruit." (Oates.)

15. Jerdon's Chloropsis. Chloropsis jerdoni.

"Seeds may often be found in its stomach, though they are not so generally partaken of as insects."

16. The Malabar Chloropsis. C. malabarica.

"Lives on fruit and insects, chiefly the latter."

17. The Common Iora. Egithina tiphia.

"I have occasionally seen it dart out and seize a passing moth or butterfly on the wing and alighting again swallow it whole, a habit which is testified to by the large Mantidæ and other winged insects which are often found in its small stomach." " Frequents orchards ..... feeding on insects which it finds among the leaves." (Oates.) 


\section{Subfam. Brachy Podinæ.}

18. The Southern Indian Bulbul. Hypsipetes ganeesa.

"Its diet consists of fruits, seeds and berries ...... it, however, also feeds on insects, and I have observed it occasionally dart at them from its perch, although its usual manner of capturing them is to seize them from the branches of trees, to which it will sometimes cling after the manner of a Tree-creeper."

19. The Madras Red-vented Bulbul. Molpastes homorrhous.

"Feeds mostly on fruit." (Oates.)

20. The Yellow-browed Bulbul. Iole icterica. Indigenous.

"I have found it to be more insectivorous than frugivorous."

"It wanders about in small flocks, feeding almost entirely on fruits and seeds." (Bourdillon.) "In all the specimens I have examined I have found fruit only in its stomach, but from the strong bristles at the base of the bill I suppose it may, at certain seasons, partake of insects." (Jerdon.)

21. The Black-capped Bulbul. Pycnonotus melanicterus. Indigenous.

"It is chiefly insectivorous, small seeds are sometimes devoured by it, and I have found snails of some little size in its stomach."

22. The Yellow-eared Bulbul. Kelaartia penicillata. Indigenous.

23. The White-browed Bulbul. Pycnonotus luteolus.

"It is both insectivorous and frugivorous, chiefly the latter, and there is nothing to which it is more partial than the seeds or berries of the latana plant."

Bulbuls are very frequently kept as cage birds, and have perhaps been more often experimented with than any other tropical bird. Those I kept years ago ate any butterfly given them, and I think it is now generally acknowledged that those species which are known to be insectivorous also attack butterflies, but they show no discrimination in eating them.

\section{Fam. D I C R U R I D Æ. Drongos or King Crows.}

All the Drongos are known to eat butterflies.

24. The Black Drongo. Dicrurus ater.

"The principal food consists of coleoptera, grasshoppers, winged termites, of which it is very fond, and ticks, which latter it takes from cattle. It has been known to devour small birds."

25. The Indian Ashy Drongo. Proc, Zool, Soc,-1911 No, L.
D. longicandatus. Migratory, 
26. The White-vented Drongo. D. leucopygialis. Indigenous.

"It is entirely insectivorous, its diet consisting chiefly of beetles, bugs, termites and such like."

27. The Ceylon Black Drongo. Dissemuroides lophorhinus. Indigenous.

"Damp forests and even their most gloomy recesses are frequented by this fine bird ...... It feeds on beetles and the many larger members of the insect kingdom which affect Ceylon forests."

28. The Larger Racket-tailed Drongo. Dissemurus paradiseus.

"Feeds chiefly at dusk when the bats come out."

The distribution of this family in the island is to be noted. The first species is confined to the Jaffna peninsula and northwest coast : I found it abundant on the opposite Indian coast in March. The second is migratory and does not breed in the island. The third is of general distribution. The fourth is confined to the heavy forests of the Western Province. The fifth to the North and Eastern Provinces.

Fam. S Y L V I D ж. Warblers.

29. The Indian Great Reed-Warbler. Acrocephalus stentoreus.

"The diet consists of small flies and minute insects."

30. Blyth's Reed-Warbler. A. dumetorum. Migrant.

31. The Rufous Fantail. Cisticola cursitans.

"The diet of this species in Ceylon consists of many sorts of small insects and caterpillars." "The indigestible parts of the food, which consists of small beetles, caterpillars and little snails, are thrown up in pellets." (Jerdon.)

32. Franklin's Wren-Warbler. Franklinia gracilis.

"The food consists of small insects, which it picks up among the dead wood to which it is so partial."

33. The Broad-tailed Grass-Warbler. Schoenicola platyura.

"Feeds on the ground." (Oates.)

34. The Greenish Willow-Warbler. Acanthopneuste viridanus. A migrant.

35. The Ashy Wren-Warbler. Prinia socialis.

"Its food consists of insects; but occasionally I have found small seeds in its stomach."

36. The Jungle Wren-Warbler. Prinia sylvatica.

"Its food consists of small coleoptera and other minute insects." 
37. The Southern Wren-Warbler. Prinia jerdom.

"It is purely insectivorous."

Fam. L A N I I Æ. Shrikes.

Subfam. LaninNe.

"These birds live entirely on insects, the Tree-Shrikes occasionally seizing a small bird or mammal. Some descend to the ground to seize their prey, a few catch insects entirely on the wing, and others, again, search branches and leaves for their food." (Oates.)

38. The Rufous-backed Shrike. Lanius erythronotus.

"A local bird ...... feeds on grasshoppers, which it entraps on the ground, and also preys on Mantidæ and dragonflies."

It almost certainly eats butterflies. I have seen it occasionally in Colombo.

39. The Brown Shrike. Lanius cristatus. A migrant.

Certainly eats butterflies. See experiments on birds in Colombo (p. 737).

40. The Black-backed Pied Shrike. Hemipus picatus.

"They are rather flycatchers than shrikes in their habits .... ... continually darting out and seizing insects on the wing." (Oates.)

41. The Common Wood-Shrike. Tephrodornis pondicerianus.

"Moths and small butterflies form a considerable portion of its food."

42. The Orange Minivet. Pericrocotus flammeus.

"Its diet consists of small butterflies and various winged insects. In the woods of the Horton Plains I saw it catching insects in the moss with which the trees are entirely covered in that damp region."

Mr. Ormiston tells me that he has known a small flock of these birds completely clear off some dozens of Papilio polytes larvæ, which he was hoping to rear on the fruit trees in his garden.

43. The Black-headed Cuckoo-Shrike. Campophaga sykesi.

"Its favourite food is caterpillars and other soft insects."

44. The Large Cuckoo-Shrike. Graucalus macii.

"Its food consists of caterpillars, grasshoppers and various kinds of coleopterous insects." Hodgson states its food to be "Mantidæ Scarabæi, berries, vetches and seeds."

45. The Little Minivet. Pericrocotus peregrinus.

"It feeds upon various larvæ (its favourite food) and small insects," 


\section{Subfam. Artamine.}

"They catch their food entirely on the wing, either by darting on it from a fixed perch or by flying about after the fashion of swallows." (Oates.)

46. The Ashy Wood-Swallow. Artamus fuscus.

This bird has been frequently quoted as having been seen by Colonel Yerbury to catch several Euploea core.

Fam. S T U R N I Æ. The Mynahs.

"They feed chiefly on the ground on insects and worms, but they are fond of fruit and berries, which they pick off trees." (Oates.)

47. The Black-headed Mynah. Temenuchus pagodarum.

$\mathrm{W}$ idely distributed and common.

48. The White-headed Mynah. Sturnornis senex.

A rare and local resident.

49. The Common Mynah. Acridotheres tristis.

See experiments on birds in Colombo (infra, p. 740).

Fam. M U S C I A P I D

"The Flycatchers feed on insects which they either catch on the wing, starting from a perch to which they usually return several times, or by running with the aid of their wings along the limbs of trees. They seldom or never descend to the ground." (Oates.)

50. The Indian Red-breasted Flycatcher. Siphia hyperythra. Partial migrant.

See experiments on birds at Nuwara Eliya (infra, p. 735).

$50(a)$. Tickell's Blue Flycatcher. Cyornis tickelli. Food?

51. The Blue-throated Flycatcher. Cyornis rubeculoides. Partial migrant.

52. The Ceylonese Dusky-blue Flycatcher. Stoparola sordida. Indigenous.

See experiments on birds at Nuwara Eliya (p. 735).

53. The Brown Flycatcher. Alseonax latirostris, Migrant. The habits of this bird are well known.

54. Layard's Flycatcher. Alseonax muttui. Partial migrant.

"In the stomach of one example I found much larger insects (moderately sized coleoptera) than I expected to find captured by so small a bird," 
55. The Grey-headed Flycatcher. Culicicapa ceylonensis.

Jerdon says it feeds on small insects.

56. The Indian Paradise Flycatcher. Terpsiphone paradisi. Partial migrant.

See correspondence (infra, pp. $728 \& 730$ ).

57. The Indian Black-naped Flycatcher. Hypothymis azurea.

Mr. Oswin Wickwar has given me the following interesting note:-

"I watched two flycatchers of this species diving into a small pond evidently in search of some aquatic insect. They both dived in the most determined manner about five or six times, and, although I looked carefully, I could not find any insects on the surface of the water. They did not swoop down and just touch the surface of the water in the manner of swallows, but deliberately dived in with a splash like a kingfisher; there was a momentary pause, and then they fluttered back to the same perch or one near about where they started from."

58. The White-browed Fantail Flycatcher. Rhipidura albifrontata.

"The chief food consists of mosquitoes and other small dipterous insects, as also the small Cicadella." (Jerdon.)

Fam. T U R D I D

Subfam. Saxicolinte. The Chats.

"The Chats feed entirely on insects they capture generally on the ground from a fixed perch, such as the summit of a stone, a stalk of grass, or a branch of a bush, and then return at once to their post of observation." (Oates.)

59. The Southern Pied Bush-Chat. Pratincola atrata.

"The food consists of insects and larvæ of various kinds, which they take chiefly on the ground." This bird is also known as the Nuwara Eliya Robin; it has very much the habits of the Stone-Chat.

60. The Black-backed Indian Robin. Thamnobia fulicata.

Has been known to capture Neptis varmona; it usually feeds just at sunset and as long as there is light.

61. The Magpie Robin. Copsychus saularis.

See experiments on birds in Colombo (p. 737).

62. The Shama. Cittocincla macrura.

"Those shot in Ceylon seemed to be entirely insectivorous, the food consisting of small beetles, ants, flies, etc." 
Subfam. Turdinx.

63. The Ceylon Blackbird. Merula kinnisi. Indigenous.

Has almost precisely the habits of the English Blackbird.

64. The Ceylon Thrush. Oreocincla imbricata. Indigenous.

"Decidedly an uncommon bird .... it appears to feed on insects which it procures beneath fallen leaves." "Thwaites says it scratches much in rubbish thrown out at the border of his plantation."

65. "The Spotted-wing Thrush.” O. spiloptera.

"Generally to be found in thick damp jungle picking up pupæ, coleoptera and other insects."

Three species of Swallow occur; one, the Common Swallow (H. rustica), is migratory, the other two have similar habits.

\section{Fam. M о т A C I L L I D Æ. Wagtails.}

There are four species of Wagtails, three of which are migrants ; the fourth, the Large Pied Wagtail, has the same habits as the rest of the family.

66. The Indian Pipit. Anthus rufulus.

" Feeds on worms and various terrestrial insects and likewise partakes of small grass seeds." I have noticed it feeding on green Aphides, and once saw it capture a Lycænid, a species of Zizera.

\section{Fam. C o R A C I A D Æ. The Rollers.}

67. The Indian Poller. Coracias indica.

"I have on several occasions seen one pursue an insect in the air for some distance and when the winged termites issue from their nests after rain, the Roller, like almost every other bird, catches them on the wing." (Jerdon.)

"Its food is chiefly large insects, grasshoppers, crickets, Mantids, and even beetles, occasionally a small mouse or shrew." (Jerdon.)

$$
\text { Family M E R O P I D E. }
$$

68. The Common Indian Bee-eater. Merops viridis.

69. The Blue-tailed Bee-eater. M. philippinus.

"A winter visitant. . . . . it feeds on wasps, bees, dragonflies, beetles, and even butterflies." (Oates.)

70. The Chestnut-headed Bee-eater. M. swinhoei.

"Locally distributed throughout Ceylon." Not found in the hill country.

These three species are well-known as butterfly-eaters; see correspondence (p. 727). 
Fam. A L C E D I I D Æ. Kingfishers.

71. The White-breasted Kingfisher. Halcyon smyrnensis.

"It occasionally, but rarely, catches fish by plunging after them, it lives chiefly on insects and small lizards and sometimes on mice and land crabs." (Oates.) "It subsists on lizards, grasshoppers, locusts, and even small snakes."

Fam. Cy P S L I D Æ̇. Swifts.

72. The Alpine Swift. Cypselus melba.

73. The Common Indian Swift. C. affinis.

These birds have all the habits of the common European Swift.

74. The Palm Swift. Tachornis batassiensis.

"Feeds chiefly at dusk."

75. The Brown-necked Spine-tail. Chcetura indica.

"Mr. Carter says that those he shot had fed on beetles, green bugs, sand-wasps and grasshoppers." Mr. Spurway informs me that he has more than once seen it snap up a butterfly. Legge says it is fond of termites.

76. The Indian Crested Swift. Macropteryx coronata.

I know nothing about the feeding habits of this bird.

Fam. Trogon I A. The Trogons.

77. The Malabar Trogon. Harpactus fasciatus.

Mr. Butler has seen a large moth brought to the nest he was observing.

"It feeds chiefly on beetles, moths or cicades; but it occasionally feeds on insects on the ground." (Blanford.)

Fam. C U C U I I D Æ. The Cuckoos.

"They feed chiefly on caterpillars and soft insects." (Blanford.)

78. The Cuckoo. C. canorus Migrant.

79. The Small Cuckoo. C. poliocephalus. Migrant.

80. The Indian Cuckoo. C. micropterus.

"Feeds on caterpillars."

81. The Indian Plaintive Cuckoo. Cacomantis passerinus. A migrant.

"It feeds on caterpillars, coleoptera and other large insects, and may often be seen taking them on the ground." 
82. The Banded Bay Cuckoo. Penthoceryx sonneratis.

"Feeds on coleoptera, Mantidæ, and caterpillars."

83. The Drongo Cuckoo. Surniculus lugubris.

"Locally dispersed .... the diet is mixed, consisting chiefly of caterpillars and beetles but often combined with various seeds."

84. The Pied Crested Cuckoo. Coccystes jacobinus. Migrant.

85. The Red-winged Crested Cuckoo. C.coromandus. Migrant. "The stomachs of those I have procured contained beetles, grasshoppers, Mantidæ, and other large insects."

Fam. FA L C O I d e. The Falcons.

86. The Kestrel. Tinnunculus alaudarius.

Has the same habits as the English bird, which has recently been shown in some instances to have butterfly-eating propensities.

The above birds may be tabulated as follows; the arrangement is artificial, and no doubt there are errors, but it is convenient. Some may be inclined to transfer the Flycatchers from group 3 to group 1 on the evidence brought forward by Mr. Marshall in the case of the European Flycatcher. I have put them in the third group, as close observation for two months showed me that two species at any rate only eat butterflies under unusual circumstances.

\begin{tabular}{|c|c|c|}
\hline $\begin{array}{l}\text { Known to feed commonly } \\
\text { on Butterflies. }\end{array}$ & $\begin{array}{l}\text { Known to take Butter- } \\
\text { flies occasionally. }\end{array}$ & $\begin{array}{l}\text { May take Butterflies, } \\
\text { especially the smaller } \\
\text { species. }\end{array}$ \\
\hline The Common Iora & Chats and Robins ... 4 & Flycatchers \\
\hline Drongos & Swallows & Babblers? \\
\hline Shrikes & Wagtails. & Warblers \\
\hline The Orange Minivet & Trogon & Swifts . \\
\hline The Ashy Wood-Swallow & Cuckoos & The Little Minivet 1 \\
\hline The Paradise Flycatcher & Bulbuls & Chloropsis \\
\hline The Roller . & The Kestrel & \\
\hline Bee-eaters & Mynahs & - \\
\hline The White-breasted Kingfisher 1 & The Indian Pipit & \\
\hline The Brown-necked Spine-tail ... 1 & & \\
\hline Tотац . . 21 & TотаL... 31 & TотаL... 30 \\
\hline $\begin{array}{l}4 \text { of the above are either mi- } \\
\text { grants (2) or partial migrants (2). }\end{array}$ & $\begin{array}{l}9 \text { of the above are } \\
\text { either migrants }(4) \text { or } \\
\text { partial migrants (5). }\end{array}$ & $\begin{array}{l}6 \text { of the above are } \\
\text { either migrants (4) or } \\
\text { partial migrants (2). }\end{array}$ \\
\hline
\end{tabular}

I would suggest this as a convenient place for a perusal of 
Mr. Marshall's paper above quoted, more particularly that part devoted to the Indo-Malayan region.

For the sake of convenience I shall designate the birds in Group 1, "The Butterfly-Eaters," and the evidence in support of this term is given below under each species.

\section{The Common Iora and, Butterflies.}

This bird belongs to the Bulbul family, another name for it being "The Common Bush Bulbul."

I have frequently watched this bird and can only confirm Legge's observations. Being so closely allied to the Bulbuls it is probable that, like its near relations, it is an indiscriminate feeder.

\section{King Crows (Drongos) and Butterflies.}

"On the 14th instant I was with Mr. C. B. Antram in a very small patch of wood surrounded by grass downs within a few miles of Ootacamund. Running through this wood was a footpath, and this path was in one place a few feet long thickly strewn with the wings of butterflies; on either side of this, for some yards along the path, were scattered wings. Just above this place three Drongos (Dicrurus) were to be seen on the trees. The weather during my visit was misty, cold and rainy, and hardly any butterflies were on the wing; consequently I had not the opportunity of seeing the birds hawking them. Dragonflies were abundant and the Drongos made frequent excursions after them, all unsuccessful so far as I saw. On examination, the wings were found to belong to the following species:-Danais limniace (or septentrionis, or both), Danais aglea, Danais chrysippus, Euploea core, Euploca coreta, Hypolimnas bolina 9 , and Catopsilia crocale. At least 90 per cent. of the wings belonged to D. limniace or septentrionis. There were several wings of Euploea, amongst which I found those of the males of both core and coreta. The remaining species were each represented by only one or two wings. These Danainæ are common in those parts, and in sunny weather would be passing in numbers through and over the wood, and the most common would almost certainly be limniace, septentrionis, core and coreta. D. chrysippus would be commoner probably on the outskirts of the wood. The only other butterflies about in any numbers when I was there, were Argynnis castetsi and Colias nilgiriensis, both eminently insects frequenting the open country, and they would seldom or never be found in anything heavier than scrub jungle. Some of the wings were obviously quite fresh, others had been beaten on the ground by rain. The three Drongos were almost the only birds about, and no other birds that we saw were likely to be capable of capturing these butterflies. It appears to me that the Drongos were certainly the cause of this extensive shower of wings; the only other possibilities are lizards or mantids, but no lizard, I should 
imagine, has either the activity or voracity to make away with such a great number of butterflies, even assuming that they settled within its reach. A mantid is even less probable, and I much doubt if there is one large enough to tackle Danainæ or Hypolimnas in the Ootacamund region.

"One would not be surprised to find an occasional Danais or Euploca sampled by a bird, but to see evidence of a systematic onslaught on butterflies which are so universally looked upon as leaders of the army of distasteful insects, and which are so widely mimicked by numerous 'unprotected' butterflies and moths, tends to make one sceptical of the accepted theories founded on the alleged value of this distastefulness. It is true that they may disagree with other birds, lizards, \&c., but if one enemy alone can effect such wholesale destruction upon them, their immunity from death by violence is so seriously impaired that it seems to me that their numerous imitators amongst the 'Swallowtails,' \&c., are simply asking for trouble.

"There was no lack of other food for the Drongos, and it can only be assumed that they found the Danainæ very much to their taste. One can hardly think of a morsel more apparently unpalatable than Telchinia violce, yet I saw a Bulbul feed its young with one within a few feet of me. It would be interesting if entomologists would give any evidence in the matter which they can. I have seen the wings of Hypolimnas misippus sometimes scattered on the road near trees in considerable numbers, and on two occasions I have seen the wings of Charaxes imna; this I imagine was not caught on the wing; if so, I must congratulate the bird on its power of flight.

Barwood Estate, Nilgiris, 20th October, 1910.

\section{H. Leslie Andrewes."}

\section{(Journal Bomb. Nat. Hist. Soc., vol. xx. p. 850.)}

This interesting observation may be held to support Mr. Moulton's proposition (Trans. Ent. Soc. Lond. 1908) that the Euploas of S. India are a Müllerian combination formed for mutual protection against the onslaught of insectivorous birds; but evidence is required that at one time they differed materially from their present day appearance.

I took the few notes following at Coonoor, 6000 feet, Nilgiris, S. India, in April 1910. I asked my collector, a half-caste who had spent all his life in the jungles, whether he had ever seen a bird catch a butterfly, and he immediately said he had, describing the Paradise Flycatcher very accurately. He said they eat the brown butterflies (E. core and coreta) and white ones. While he was speaking I happened to open an envelope containing Danais septentrionis, and he exclaimed, "I have seen them eat those too." He added the bird nips off the wings and swallows the body; also that they catch and eat the Ornithoptera. A few days afterwards I was at Kullar at the foot of the hills, about thirty miles from Ootacamund, where these birds and Drongos are common. I saw a Drongo in a lane, and close together on the ground 
I found the wings of Papilio hector, Euploea core, and Danais septentrionis, and a little distance further on another D. septentrionis. These were the commonest butterflies about at the time.

12.4.10. Kullar, 1200 feet. Saw a Bulbul dart out at a Papilio hector and miss it. Saw the following with notched wings : $P$. demoleus, one or two Catopsilias, one or two Teracolus fausta, several $P$. hector, many Junonia lemonias, these last usually with oval pieces out of the secondaries, probably by Calotes.

10.4.10. Coonoor. Walking along a road I saw what I thought, at first, was a leaf falling from a tree about twenty feet up, but on going to look at it $\mathrm{I}$ found it was the fore wing of $H$. misippus $q$, diocippus form. It is curious that I have only seen one other female during the many times I have been along this road. I could not see the bird, but Bulbuls are plentiful. Found also on the road the fore wing of Papilio sarpedon.

21.4.10. Kullar. Watched a Racquet-tailed Drongo for some time hawking after flies. I did not see it chase a butterfly though there were numbers ftying about, chiefly Euplœas.

Mr. T. N. Hearsy, Indian Forest Service, writes :- "Coimbatore, 6.6.10. . . . . I have frequently seen the common green Bee-eater (Merops viridis) and the King Crow (Buchanga atra) take butterflies on the wing, the butterflies being Catopsilia pyranthe, C. florella, Terias hecabe, and Papilio demoleus. The Bee-eater I have also seen taking Danais chrysippus and Danais septentrionis, and I remember to have been struck with their taste for those latter. . . I have also seen the Tree-Swift (Dendrochelidon coronata) take Catopsilia pyrarthe."

In another letter he mentions having seen Drongos attacking dragonflies.

Mr. Ormiston, of Kalupahani, Hadumulle, Ceylon, 4500 feet, writes :- "Kalupahani, 4.2.09. Of course I will try and get you any notes I can on birds eating butterflies .... I can give you very little assistance at present, as the only bird I have watched is the Fork-tailed Drongo, who eats the whites during a flight and attacks Kallima.

"The Magpie Robin and black-and-white Flycatcher catch a great lot of moths, but I have no notes of their taking butterflies. At Ohiya bungalow, after a moth night, we used to bottle all the moths we wanted, and then loose a tame Mynah who made short work of the rest, but I never tried him with butterflies. I will try the Robins in my garden, but the fact that they eat dead butterflies will not prove that they catch them. Personally I do not think birds make any appreciable difference to the number of butterflies except possibly by eating them in the larval stage. It is quite unusual to see a butterfly caught."

"Kalupahani, 3.1.10. I have kept my eyes open for butterflyeating birds, but I am sure that the slaughter, if any, must take place in the larval stage. I have seen the Fork-tail Drongo feeding on the flight whites and Kallimas, but that is all.

"I have seen a dragonfly catch and kill Zesius chrysomallus and another fly killing Papilios, Lycænidæ, Syntomiidæ, with 
apparently preference for the last named. Some black-and-white Flycatchers come close when I am beating for 'plumes' on the road here, and catch lots of common Pyralids I put up. The common Magpie Robin comes most mornings for the moths which I have slain at the lamp and discarded, and I have seen a Sparrow catch a gold-tail moth. But since you asked me a year ago to look out, I have not seen half a dozen cases of birds eating butterflies."

"Kalupahani, 26.6.10. I have kept my eyes open for birds eating butterflies but have no new notes. During the last flight the Fork-tailed Drongos were as usual feeding on the white butterflies, but that is the only instance I have seen. Certainly few, if any, birds eat the Terias family. I have watched them flying slowly with Swallows, Drongos, and Flycatchers close to them and leaving them alone. I fancy Bee-eaters take butterflies, but they are scarce here, and I have no data therefore to go on ......

"Kallima philarchus appears at Hadumulle in large numbers and the flight lasts for about a week. The biggest flights are very nearly always from about Christmas to the New Year, but a smaller flight appears in July. About once in four years they are especially common . . . They seem especially to favour Loquat trees, but come readily to a mixture of jaggery (native sugar), beer and rum. Instead of settling on the branches or trunk with their heads towards the top, they seem usually to do the opposite, and are therefore apparently very conspicuous; but the birds do not seem to notice them till they move (when they come to sugar they settle anyhow).

"The spot where I mainly catch them is about two acres of Grevilleas planted with a few Loquats. When the flight is on, the Grevilleas seem full of Forked-tailed Drongos, and as soon as a butterfly moves a Drongo darts for him, but usually only takes a big piece out of one wing. I have never seen the wings lying on the ground, so fancy if the Drongo gets him he eats wings and all. I have never, however, seen him catch one."

"10.10.09. Paducka. Watched Drongos (Dicrurus leucopygialis) hawking for flies; though Mycalesis ceylonica and small Lycænids were flying plentifully beneath the birds, they did not take them.

"19.12.09. Paducka. Watched several Drongos and a Paradise Flycatcher; the former frequently caught small flies in the air and occasionally came to the ground after bigger insects, but only once did one catch a lepidopterous insect and this seemed to me a moth. The Flycatcher took short flights on the ground picking up flies, but certainly not a butterfly. Came across five fully fledged Ashyheaded Babblers sitting all together on a branch; they flew off only when I approached quite close to them, with great chattering, very much like the ordinary Babblers; the old birds were hunting for food in the thick bamboo jungle. This is very late in the year for young birds."

I give these merely as samples of negative notes; there is no object in giving more. 
"With regard to the capture of butterflies by birds, I was told (in May last) by a lady who was staying with us, that she had been watching the Drongos in these Gardens busily catching butterflies. From her description, the victims seemed to be species of Euploea. She said that the birds bit off the wings, and that the road was covered with the dismembered wings. I asked her to collect some of the wings for identification. But, in the meantime, they had either been swept or blown away, and she could only produce one or two wings of Papilio jason and Jamides bochus."

The common brown Euplœa can hardly be mistaken for any other Ceylon butterfly.

\section{Shrikes and Butterflies.}

Dr. Willey, F.R.S., writes:- " The late Grant Allen stated positively that among the animals which he had seen in Butcherbird's larders were mice, shrews, lizards, robins, tomtits, and sparrows; but he added that in spite of its occasional carnivorous tastes, the Shrike is at heart an insect-eater."

The few experiments I have been able to make leave little doubt in my mind that they make little or no selection in their butterfly diet. See below (p. 737).

\section{The Orange Minivet and Butterflies.}

I know nothing about this bird's provender other than already given; Mr. Ormiston's observation is, however, suggestive. The larva of Papilio polytes lives in its earlier stages exposed on the upper surface of the leaf of the orange or citron, looking exactly like a bird's dropping; when irritated it shoots forward two fleshy "horns" emitting a pungent smell of orange, which is higbly disagreeable. I presume this is derived from the food-plant, and if this be so the larva in all probability has a taste of unripe orange, and consequently it would seem that the bird's palate is not highly educated and its taste in butterflies probably not selective.

\section{The Ashy Wood-Swallow and Butterfies.}

Mr. Walter A. Cave writes :-

"Colombo, 21st October, 1910.

"I am sorry I cannot help you much in regard to the question of butterflies being taken by birds. On one occasion I observed an Ashy Wood-Swallow (Artamus fuscus) tearing the wings off a butterfiy, then swallowing the body. This was in Peradeniya Gardens a year or so ago. There were many of these birds, which are allied to the Shrikes, hawking over the Maha Weliganga river. I did not see this particular bird actually catch the butterfly, but I have every reason to believe it did, because I had a good pair 
of prism binoculars focussed on the bird as it alighted in a tree. As I have said, the wings were first stripped, and as they fell I was able to make them out. I am not well acquainted with butterflies, but to make my notes complete I referred to the Museum and determined the butterfly as the commonest brown one we see about the roads here, and I put it down as Euploea core.

"On another occasion I saw a Common Swallow (Hirundo rustica) take a small white butterfly, but I was too far away, and without my glasses, to determine the species. The Swallow was hawking near a piece of very dark jungle, near the Nuwara Eliya lake, and the white butterfly was very conspicuous against the background."

Colonel Yerbury's note of this bird being seemingly partial to Euploca has already been alluded to.

\section{The Paradise Flycatchers and Butterflies.}

Mr. John Pole, Scarborough, Maskeliya, 6000 feet, writes :"Maskeliya, 13.3.09. . . I seem to recall the attacks of the Odonata and even Asylus (Diptera) on butterflies, but I never remember an instance of a bird attacking one - I have watched the little Tailorbirds eating the larvæ of Terias hecabe and that with seeming distaste, and the Elycatchers at work on Diptera from the shelter of some leafy tree; I have had so large an insect as Phyllades consolisma taken from under my very nose by a Drongo, have had moths beaten from a fence in the daytime stolen by Swallows ere I could net them, but have never seen a bird in Ceylon carry off a butterfly. In England I have seen a Swallow carry off Papilio machaon whilst I was following it ... I came out to this Island in 1871."

"Maskeliya, 17.3.09. Since writing on 13th we have had for two days (16th and 17th) flights of butterflies, the first I have seen this year. There has been in my garden for the last three months a bird, which generally goes by the name of the 'Cotton Thief' (the Paradise Flycatcher). This bird occupies a jak tree within twenty feet of my window, and for the last two days he has been obtaining all his meals from the flights of butterflies, and although I have never actually seen him eatch one, I have seen him circling from the tree in pursuit and the wings of the insects he captures falling around the base of the tree within a radius of twenty feet. Should they be of any service to you, I can send you the wings of Appias paulina and varieties $\delta$ and $q$ as follows :-

Upper left wing, 4 o 2 q.

Upper right wing, 5 of 5 .

Lower left wing, 5 ㅇ.

Lower right wing, 20 .

"Maskeliya, 14.4. . . I have only one more species of butterfly to give you as its food-Papilio agamemnon, and this is the only 
butterfly to my best belief the bird has taken since my previous letter on the subject. The bird is rare here .... We have had no flights of the yellow and white Catopsitias this year-so no wings about - the Appias victims were mostly the white forms 0 and $q . "$

\section{The Roller and Butterflies.}

I am unable to add much regarding this bird's dietary. It is found only in the dry northern districts and is uncommon. In the plains of India it is a familiar occupant of the telegraph-wire, and I have often seen it chasing and no doubt catching various insects from such a perch. I have no doubt it catches butterflies, and more than once am sure I have seen it do so, though I am unable to name the species captured. Judging by its very varied menu, I have little doubt that it pays little heed to the species it manages to catch, but of this I have no direct evidence.

\section{Bee-eaters and Butterflies.}

Mr. Fred. Lewis, a well-known ornithologist, writes:-_" Colombo, $8.11 .09 \ldots \ldots 1$ have noticed Swinhoe's Bee-eater in particular. hawking after the common so-called 'Adam's Peak butterfly' [Catopsilia and Appias], and it appears to prefer the white one to the larger yellow fly. It does not, so far as I am aware, take any of the large brown butterflies often to be found with the above named. I have watcher the bird when quite a selection of flies could be made, but beyond taking the white and an occasional yellow, I have never seen it feed on others. I am not prepared to say, however, that the Bee-eater does not eat any other butterflies than the two mentioned.

"Our common black King-Crow appears to select the same flies, taking them on the wing in the same way as the Bee-eater. Swallows do not, so far as my observations go, ever touch any butterflies.

"It is remarkable, however, on such occasions as one finds in the dry zone, when vast masses of these 'Peak' whites and yellows congregate round some wet pool or damp ground, that King-Crows are not found taking the opportunity of a 'square feed.' I infer therefrom that the butterfly is only a 'side dish' and not a regular item of food. . . I cannot recall an instance of young birds being fed with butterflies. I suspect the difficulty of swallowing the wings is the reason, for I cannot say I have ever found small nestlings with anything so difficult of mastication in their nest. ..."

In another letter Mr. Cave writes :-

"Belvedere, Colombo, 5th March, 1911.

"In reply to your letter I am sorry to say I have nothing. further to report on the subject of the capturing of butterflies by 
birds. I have the subject always in mind when I happen to get out, and my friend Mr. Symons, of the Government Training College, is also on the look-out, and if we should notice anything it will be reported to you.

"Being keen on birds there is very little that escapes my notice when I happen to be out, and I must say the subject on which you write is very exceptional so far as my observations go. At Christmas time I motored round the south coast to Galle, Hambantota and from thence to Haputale. The butterflies were there in myriads, nearly all the way-none of us had ever seen anything so remarkable in our lives. There were literally clouds of butterflies-in fact we remarked that we now knew where all the butterflies came from which used to appear here on migration in the N.E. monsoon. But neither Mr. Symons nor I saw a bird attempt to catch a butterfly, and we saw a large variety of birds including Bee-eaters, Swallows, and Swifts."

An argument of some force against the frequency of butterfly victims may be advanced by the different behaviour of birds in the presence of a flight of locusts and a migratory flight of butterflies. I have been fortunate enough to witness both, and the difference is very striking. In the former, every kite, crow, and insectivorous bird in the district follows the locusts, gorging to repletion; and it is a very remarkable sight the numbers, I might almost say flocks, of birds following the swarm. In a migratory flight of butterflies, on the contrary, with the exception of a few Bee-eaters and Drongos, birds are conspicuous by their absence.

Mr. Oswin Wickwar, F.E.S., sends me the following note:"When shooting in the Northern Province in May last, I was crossing the dry bed of a river when a Bee-eater (Merops viridis) swooped down and caught a butterfly on the wing within a couple of yards of my face. The instant it snapped it up, the fore and hind wings of the butterfly floated down in front of me, and enabled me to prove its identity, Papilio polytes of. This was about 11 A.м. The following morning about 7 A.M. I had occasion to cross the same spot, and saw what was probably the same bird perched on a twig; I had hardly seen it, when it flew down and entered a hole in the bank, but came out again in a few seconds. This was evidently its nest, and I was anxious to look for remains of insects, nor was I disappointed. By introducing a twig, the hole seemed to be about two feet deep and to travel in a horizontal direction, so a start was made to cut away the bank, and before going a foot three insects were unearthed,-a humming-bird moth (Macroglossa sp.?) which was still alive, a 'skipper' (Suastus gremius) also alive, and a small green beetle with white spots on the elytra. All these were secured and taken away. The hole now took a turn and went a downward course for about two feet, which meant cutting away a huge piece of the bank to get at the nest, so I had to leave it." 
The following extract is of much interest ; it is from the 'Spolia Zeylanica,' 1910 :-

\section{"Bee-eaters as Fish-eaters.}

"There are a pair of Chestnut-headed Bee-eaters (Merops swinhoei), which nest pretty regularly in a steep bank on a road below my bungalow, and about 150 yards distant from my pond. Almost any bright afternoon, between 2 and 3 P.м., they may be seen fishing in the pond. They come down from a dead tree, which stands on a knoll some 50 yards away; sometimes hovering for a moment over the water to locate their prey, but more commonly marking it in their swoop, and dashing headlong into the water like a kingfisher and very rarely missing their fish. I have seen the pair account for a dozen fish in as many minutes; all quite small fry.

"When there is a flight of white butterflies on, these birds devote most of their attention to them throughout the day, but on warm bright days nearly always have a go at fishing in the afternoon.

"I have always hitherto associated Bee-eaters with the one diet of insects; and I could not quite trust the accuracy of my eyesight until I brought a strong pair of field-glasses to bear on the actors at the short range of 15 to 20 yards. I think it probable that many so-called insectivorous birds change their diet when some chance has put them up to the taste of a new article which happens to suit them. . .

"Since the pair, which I convicted of fishing, hatched out their young, they have abandoned their fishing expeditions and may be seen sitting on the tree facing their burrows catching insects (chiefly white butterflies) to feed their nestlings.

\section{E. Gordon Reeves."}

Wiltshire, Matale, May 7, 1910.

\section{The White-breasted Kingfisher and Butterflies.}

I have often seen this bird eating grasshoppers, and on one occasion a butterfly which I was too far off to identify. Small frogs and lizards, some of the latter of quite a respectable size, I have also seen taken. Dr. Willey writes, "I remember being much surprised, many years ago, to find a Kingfisher's stomach full of insect remains." With such a mixed dietary its taste for butterflies is probably impartial.

\section{Sparrows and Butterflies.}

Mr. R. D. Hodgins writes:- " April 1911. These birds have built their nests about my bungalow here at Matale, so I have plenty of opportunity of watching them. I have on three

Proc. Zool. Soc. -1911 , No. LI. 
occasions noticed the birds hawk and catch butterflies in mid-air, and in two cases the butterflies caught were taken off the tree tops, but I could find no trace of them on the ground.

"The flies on one of these occasions were brown and on the other white, very like the common white cabbage butterfly of England, but I was some distance away and couldn't see them properly [probably Euploca, and Caiopsilia or Appias].

"On the third time the butterfly was caught while passing the bungalow one sunny afternoon in February, but appeared to be released the moment later and dropped to the ground. Only its abdomen was taken and this was nipped off neatly at the waist. These wings I collected and herewith enclose [Papilio sarpedon: the butterfly was otherwise in remarkably good condition; it is a very rapid flier.]

"I have often seen a sparrow dive and catch a feather floating in the air in a similar way to that in which a swallow does. Whether the feather is mistaken for a butterfly or vice versa I don't know.

"In the case of Ceylon native birds, I have been unable to detect any catches of butterflies, but have noticed that two of the species will take and devour moths ..... This bird [the White-bellied Drongo] I have often seen catching flies from the branch of a tree or telegraph-wire with downward swoop on to the victim. I have often seen it catch small moths up to about one inch in length, which it seemed to devour, wings and all, after returning to its perch."

It would be as well to refer to the distribution of the "Butterfly-eaters." The Drongos have already been alluded to; only one is of general distribution. The Common Iora is widely distributed. The Shrikes with two exceptions are found in the wooded country of the upper and lower hill districts, the other two I have seen only in the low country.

The Ashy Swallow-Shrike is a partial migrant in the island ; it appears in small flocks in Colombo during the north-east monsoon, at other times it is more an inhabitant of the north. The Roller is found only in the dry districts, so also are the Bee-eaters, particularly the Green Bee-eater, which is never found in the wet country or above 300 feet. Swinhoe's Bee-eater occasionally ascends higher, and the migrant Philippine Bee-eater appears for a short time on the wet western coast at the break of the northeast monsoon, but soon retires to the dry northern districts. The White-breasted Kingfisher and the Brown-necked Spine-tail are of general occurrence.

If this distribution is carefully studied, it will be noticed that there is a distinct paucity of butterfly-eating birds in the wet hill districts and that part of the coast subject to heavy rains; though mimicry occurs quite as commonly, if not more so, as in the drier districts, where butterflies are less commonly met with. 


\section{Experiments on Wild Birds.}

The following experiments were made on one bird in column 1, two birds in column 2, and two in column 3 (see p. 724), a very small percentage of the total number no doubt, but the best I could do under the circumstances, and they indicate the lines for future investigations.

\section{Experiments on Flycatchers at Nuwara Eliya, 1909.}

The Indian Red-breasted Robin Flycatcher, Siphia hyperythra.

This bird is migratory and is found only in the hill districts ; it is about the size of the European Spotted Flycatcher.

30.3.09. Deprived live Terias hecabe one, Terias libythea one, Hypolimnas bolina ơ one, Danais fumata one, Neptis leucothoë one, and Appias galene one, of about two-thirds or three-quarters of their wings, and put them on the ground near a tree from which one of these birds was accustomed to feed. It first made off with either the Neptis or Danais, I could not see which, then the Appias. It then flew away, and I picked up one of the Terias and Hypolimnas. This last had a good deal, perhaps half, the wings left and fluttered about vigorously.

1.4.09. Lethe daretis one, Vanessa haronica one, Terias hecabe one, and the same $H$. bolina, treated in the same manner as on the last occasion and put in the same place. The bird carried off the first two, but the $H$. bolina seemed too large for it, as it was for another Flycatcher which came along shortly after the first had flown off. I could not see what became of the $T$. hecabe. The same afternoon a similar experiment, but with no result.

9.4.09. This bird has evidently migrated as I have seen none sirice the last note. It nests in the Himalayas.

\section{The Ceylonese Dusky-blue Flycatcher, Stoparola sordida.}

This bird is peculiar to Ceylon but confined to the hill-tracts.

2.4.09. Placed Terias hecabe two dead, Argynnis hyperbius one, Danais fumata three, Appias galene one, these latter alive but largely deprived of their wings, near the cherry-tree much frequented by Flycatchers. The cock bird carried off one $D$. fumata, its mate another ; the latter I was enabled to watch closely, and it had extreme difficulty in swallowing the fly on account of the wings. The former shortly afterwards returned and carried off the remaining $D$. fumata, but the latter seemingly had had enough of it. Shortly after a Red-breasted Flycatcher flew off with the Appias. What became of A. hyperbius I do not know, but the two dead Terias were untouched.

Numerous specimens of the above butterflies were flying about at the time, but I have never seen these Flycatchers molest them.

5.4.09. Placed T. hecabe one, D. fumata one, and A. hyperbius 
$f$ one, under the cherry-tree, having amputated both wings on one side close to the body. The cock bird flew down almost immediately and seized $D$. fumata, and as usual it had great difficulty with the wings; about ten minutes afterwards it took the A.hyperbius, but $T$. hecabe was left. I fancy the wings rather "put off" the bird.

29.4.09. The birds have a nest with young in a cherry-tree in the grounds. I put down A. hyperbius o , $T$. hecabe, Neptis leucothö̈, and one or two others; they had all been dead some days and were very dry. After some time the bird noticed them, flew down and seized the Argynnis, which had its wings closed and showing the underside. It flew with it into a tree but very shortly dropped it, it was evidently too dry. I found it had been caught by the fore wings, one of which was gone with also a portion of one hind wing. The same afternoon put down live Pyrameis cardui, N. leucothoë, T. hecabe, Appias nadina, and Euploea core, but with both wings on one side removed. The cock bird flew down among them and caused a great flutter; it first caught the Terias, then the Neptis, and lastly the Euploea, which provided a great chase. It carried them altogether to the nest, but in feeding the young, the Euploe escaped; the bird was after it in a flash, caught it again and carried it back to the nest. It was very interesting to watch its efforts to get such a large insect, the size of our Camberwell Beauty, into the young one's mouth. Three or four times it had to take it out and manipulate it in its own beak before another trial; eventually, it succeeded in forcing it down the youngster's gullet.

2.5.09. A half-winged live A. hyperbius placed near the nest. I am sure the bird noticed it, but beyond regarding it carefully it did not molest it.

I am convinced from long and repeated observation that the old birds never fed on butterflies themselves or fed their young with them. A critic, whose opinion I value highly, has objected that because I never saw one of these birds capture a butterfly, it is no proof that they did not do so and that very possibly the difficulty of catching them would only induce pursuit when the butterfly was off its guard and a capture possible. I do not know why the birds should be more coy of capturing a butterfly than a house-fly in my presence, and I can scarcely believe they took the opportunity of my absence to do so. Granted that difficulty of capture was the reason for nonpursuit, what chance, it may be asked, would a young bird with considerably feebler power of flight have of conducting a series of tasting experiments on these butterflies? It is not infrequent in the writings of advocates of mimicry to explain the rareness of attack by difficulty of capture; but by doing so they seemingly forget that if such is the case with old birds, it makes tasting experiments (with butterflies) very difficult for young ones. 
Experiments on Birds in Colombo.

The Brown Shrike. Lanius cristatus.

28.12.08. Pinned a large Hypolimnas bolina $q$ (a mimic of Euplœas) on a paling : in a few minutes the bird came along, and directly it saw the butterfly it pounced upon it and carried it off, and I could not see where it went, but I have no doubt it ate it.

29.12.08. Pinned a Hypolimnas misippus $q$ on the paling. The same Shrike saw it, seized it and held it in its claw, eating it piecemeal and tearing off two or three wings. The following day the same experiment was repeated with Danais chrysippus and Telchinia violce, with the same result.

6.4.09. Nuwara Eliya. Noticed one of these birds, perched on a twig, fly down and capture some insect on the ground. I watched it for a long time, but though many butterflies flew past, it took no notice of them. They comprised principally Argynnis hyperbius, many Appias sp. ? Euploca core, Terias hecabe, and Lethe daretis.

28.11.09. Colombo. Put down Delias eucharis + , several Euploea core, Danais limniace 2, Papilio hector, and Telchinia violce alive but mutilated. A Shrike came and looked at them keenly from a tree close by, but did not attack them. A small Cuckoo flew over them twice, but took no notice of them.

21.10.09. Put down H. misippus o 5, E. core 4. The Shrike, perched in an oleander bush, evidently saw them, but for quite an hour took no further notice though it took several insects close to them. It eventually took one, perhaps two, Euplœas. I picked up the others.

\section{Magpie Robin. Copsychus saularis.}

25.1.09. Put a number of Terias hecabe (unpalatable) in the porch of my house, where the Robin comes to feed morning and evening; some had their wings removed, but it took no notice of any of them.

4.2.09. Placed $1 T$. violce, $1 \mathrm{E}$. core, $2 T$. hecabe, and 1 Precis lemonias wingless, and 1 normal $T$. hecabe on the veranda. The bird ate the Euploea with difficulty owing to its being very dry, and it took the body of the wingless $T$. hecabe in its bill, but dropped it almost immediately as it was too dry ; it took no notice of the others.

6.2.09. Placed specimens of the above on the veranda dead but uninjured, and a wingless $T$. hecabe; the bird ate the latter but took no notice of the others.

Mr. Ormiston informs me that a Magpie Robin in his garden has become so confidential as to take food from his fingers and that it will eat "almost any kind of butterfly when thrown to it," but he has never seen it catch one. Neither have I during the seven years I have closely observed this species.

21.10.09. Put down E. core 5 and D. chrysippus 1, with the wings on one side removed. A young Magpie Robin, as shown by its speckled breast, captured one Euploea, and though evidently 
somewhat alarmed at its size, killed it and, after the usual difficulty with the wings, swallowed it. It immediately captured and ate a second, third, and fourth ; this last was a very vigorous insect and fluttered a good deal before it succumbed. The bird was then frightened and flew away, but carried the Euploea with it; it took quite another ten minutes to get rid of the wings, and during the process it twice flew off to capture small flies ; it eventually swallowed it. The D. chrysippus was, I have no doubt, eaten by a Calotes which ran out of the grass close by where I had put it.

22.10.09. Put down 2 Eupleas, one dead and one moribund, 1 Hypolimnas bolina o dead with wings closed, and $3 H$. misippus ot alive and all lively. The young Robin immediately flew down and tackled the Euploca, mangled it for some time and then dropped it and flew away; it returned shortly afterwards, picked it up and flew away with it. Directly after, another young bird flew off with and devoured the other Euploca. This attracted the notice of the old birds, one of which, I think the cock, flew down, but before he could seize a butterfly was hustled off by his mate, who picked up two H. misippus and flew off with them. The one $H$. misippus and $H$. bolina were left.

26.10.09. Put down H. misippus o 2, H. bolina o 1 , Junonia (Precis) almana 2, Pyrameis cardui and Catopsilia pyranthi, all with wings on one side removed. The $H$. misippus fluttered most and attracted the attention of Calotes versicolor, which pounced on and ate both of them ; something then frightened it off. Next an old cock Magpie Robin caught sight of the $H$. bolina, seized and killed it after a lively chase, and finally disposed of it. It was a very long time beating off the wings and made many attempts to swallow the fly, before it was finally successful. Three or four times I thought the bird was going to leave it altogether. After swallowing the fly, it went off and drank at the runnel close by. Shortly afterwards, a young one of the same species caught sight of the Junonia and captured it; this disturbed P. cardui close by, and the bird dashed from one to the other, not able to make up its mind which to take, when the old hen bird came and tried to get one, but the youngster was too sharp for her and managed to swallow both. I should have said that this bird hopped over the Catopsilia, which was moribund and motionless, to seize the Junonia.

Note. I have now little doubt that so long as the butterfly is motionless, resting, as these mutilated butterflies generally do, with their wings expanded, they do not attract attention; but directly one moves, whatever the species happens to be, it is the one to be seized and eaten, even though so-called palatable species are close by. All these butterflies are flying commonly in the garden, but I have never seen them molested.

28.10.09. Put down H. misippus के 2, E. core 2, Catopsitia pyranthi 2, Terias hecabe 1. The Robins came for them the moment I went off; the old cock bird seized one Euploca and made off with it, and the young bird the other; this latter, after 
ineffectual efforts to break off the wings, left it and caught a Catopsilia and ate it at once, and then the $H$. misippus, afterwards perching just above the place where I had put the butterflies. The old bird saw the Euploea which had been killed by the young one and regarded it for some time, then it flew down, pecked at it, looked at it again and then flew off with it. The $T$. hecabe managed to struggle into the grass and was lost.

Curiously enough, while this was going on, a Catopsitia pyranthi was actually laying eggs within two feet of where I had put down these butterflies, and within twenty feet I found this afternoon eggs and larvæ of Euploea on the oleander. This seems to me to show that the butterflies, when whole, are not molested because, I suppose, they are difficult to catch.

12.11.09. Put down three $H$. misippus $\delta$, one a partial cripple, the others with two wings off. An old hen Robin came at once, and flew off with one of the wingless ones to a bush about twenty yards off and ate it; but it did not seem very hungry. A young one a few minutes after came and took the crippled fly and ate it after the usual difficulty ; it came back in a minute or two and ate the third one. The butterflies had emerged in the morning and were consequently full of juice.

16.11.09. A young Robin made off at once with a newly emerged H. misippus ơ .

18.11.09. Put down four mutilated recently emerged $H$. misippus $\delta$. The young Robin flew off with one from which the wings had been removed and ate it; a few minutes after an adult cock Robin came and ate the three others one after the other.

19.11.09. Put down four mutilated recently emerged $H$. misippus $\delta$ in the front garden on the drive. A Calotes ophiomachus ran off with one and a Brown Shrike (Lanius cristatus) with two others; the fourth, which had its wings only partially developed, got into the grass, grew its wings, and eventually flew off. I released three or four butterflies at the same time, and they flew off strongly enough and were not chased by the Shrike, which was sitting on a tree close by me.

21.11.09. Put down three H. misippus 우 form diocippus, which resembles Danais chrysippus; the hen Robin came at once and ate one and flew off with another; a young bird followed its mother, and flew off and ate the other. These butterflies had hatched out that morning and the wings on one side had been cut off. I next put down five more females, all with two exceptions with the wings entirely removed. The cock bird took one of the half-winged ones and then ate a wingless one. The young bird then returned and finished off the remainder. These female butterflies evidently derived no protection from their resemblance to $D$. chrysippus, and so far as two species of birds are concerned, H. misippus is a palatable butterfly.

8.1.10. Found Lycana (Zesius) chrysomellus of fluttering on the ground; it was headless and with a piece out of one hind wing, probably caused by a Sparrow. 
During this month (November 1910) I have been breeding Hypolimnas misippus freely, and the Magpie Robins come every morning on the chance of getting one. I have tried them with both males and females, crippled and perfect, and always with the same result. They are immediately seized, well beaten, and swallowed after considerable difficulty. I noticed on one occasion a perfect female resting on the ground with wings widely expanded but insufficiently strong to fly ; the resemblance to $D$. chrysippus was perfect, but the Robin seized it without hesitation.

One day the large Hill Crow-an occasional visitant-carried off a crippled male with wings quite undeveloped; it pecked at it twice and then dropped it, shaking its head with every appearance of disgust. I remembered that the insect had fallen into and was well covered with the red liquid these butterflies always evacuate on emergence, and thinking that this was the cause of the Crow's discomfiture, I covered a crippled female with the stuff and threw it on the ground : a Magpie Robin soon came and saw it, and shook its head once or twice after pecking at it, but it swallowed it in a short time.

Mynah. Acridotheres tristis.

This bird belonged to Mr. O. Wickwar, F.E.S., who kindly assisted me. The bird was quite young and was allowed perfect liberty in a large garden, where it fed freely on grasshoppers and other insects; it had abundant insect food, and was also accustomed to fill up its dietary by visits to the kitchen for odd scraps. I have placed in brackets the presumed palatability or otherwise of the species experimented on.

3.1.09. Given Euploea core (unpalatable), took it readily, but the wings seemed to bother it considerably, so gave it another with its wings shortened, this it ate readily enough and then went back and finished off the first one. We then gave it Papilio lankeswara (palatable?) which was also readily eaten. Half an hour after gave Papilio (Menelaides) hector (unpalatable); this puzzled it for a bit and it seemed disinclined to eat it, evidently on account of the large wings, for when these were removed it ate the body with relish, even hopping off the veranda after it when it fell over the edge. A couple of Telchinia violce (unpalatable) (an Acræine) $\delta$ and $q$ followed, and then Hypolimnas bolina of (unpalatable ?) and Delias eucharis (unpalatable); all these received a pinch on the head, were well pounded, wings partially removed, and the remainder eaten.

24.1.09. The bird had been kept without food for some time and was decidedly hungry. 3 P. hector, 1 T. viole, 1 Myculesis ceylonica (palatable?), and 1 Polyommatus botica (palatable?) were put in a row outside the cage ; when this was opened the bird hopped over them and made straight for the kitchen, where it was accustomed to pick up odds and ends. After some persuasion it ate 1 P. boetica and 1 Lyccena (Zesius) chrysomellus $q$. Some three hours afterwards it ate 1 Precis almana (unpalatable), 
1 Papilio hector and $1 P$. aristolochice; it seemed a good deal worried by the wings. Afterwards neglecter $M$. ceylonica and T. violae, but ate one wingless Euploca core.

The conclusion we arrived at from the above experiments was that butterflies were not its natural food, but that when hungry it would eat them indiscriminately, and that the palatability or otherwise of butterflies was of no account with this species of bird.

The dietary of Ceylon insectivorous birds is fairly well known, and we are now in a position to discuss the questions-Do the birds of this island eat butterflies largely? If so, do they eat them in sufficient quantity to produce any form of mimicry ? and do they show any discrimination in their attacks? In other words, can the terms palatable and unpalatable as applied to butterflies be maintained.

As regards the first question, it will be granted that there is a greater destruction of butterfly life than has hitherto been supposed, and the following observation on a Bee-eater, though necessarily a rough one, shows clearly that the destruction is sufficiently severe to produce mimicry, provided of course that the agents showed sufficient discrimination in their attacks.

The road from Trincomali on the north-east coast to Anuradhapura, runs through fifty-eight miles of thick forest which is cut back some thirty paces on either side, thus affording a convenient place for butterflies which avoid the dense jungle. Between the hours of 9 A.м. and 10 A.м., I counted the number of butterflies between the third and fourth milestones from Anuradhapura, and they came to one hundred and ninety-five: the same day, in the outskirts of the town I watched a Bee-eater feeding from 12.45 to 1.45 P.M., and during this time it caught twenty insects; on only one occasion could I be certain that the capture was a butterfly, and this was undoubtedly Catopsilia pyranthi. The bird feeds from about eleven o'clock till five.

Motoring between these two places I calculated roughly that there was a pair of these birds to the mile*, and consequently the whole of the butterflies along this road would be cleared off in about a fortnight unless they received an accession of strength. The calculation is necessarily a rough one, but it gives a good idea of the struggle for existence that is constantly going on. This observation was made January 7 th, 1909 , at a time of year when butterflies are less numerous than usual.

The question whether discrimination is shown by birds in their attacks on butterflies is of the greatest importance in mimicry, and on the answer depends the fate of both Batesian and Miillerian mimicry.

I do not attach much importance to the fact, curious though it is,

* Bee-eaters are particularly fond of perching on telegraph-wires. 
that in the observations I have been able to collect, the Euplœines and Danaines, popularly supposed to be highly distasteful, figure more largely as virtims than any other group. I believe this to be simply due to the fact that these butterflies occur in very large numbers, and not that distinct preference is shown for them. Admitting that more evidence is needed, I doubt whether future investigations will reveal any marked preference in those birds which are mainly instrumental in the destruction of butterflies, for the reason that their dietary is of such a mixed character; and if this were so, or if what I have here set forth be considered sufficient to settle the question, it is difficult to avoid the conclusion that the unpalatability of these butterflies has been assumed on insufficient data. It is interesting to recall Professor Meldola's remarks written so long ago as 1879 , when Müller first propounded his theory of mimicry (Proc. Zool. Soc. Lond. 1879) :-

".... it may be fairly asked how far we know that such imitated groups as Heliconius, Euploea, Danais, Acrcea, etc., are distasteful. But very few observations have, as far as I am aware, been made even upon these groups which are generally admitted to be the objects of imitation, and I certainly know of no systematic experiments conducted with these models and their insectivorous foes."

The Bee-eaters seem to show some partiality for the yellow and white butterflies of the Catopsilia and A ppias group; but whether this is more apparent than real is not clear. It may be that these butterflies are more readily seen and easier to capture than others; but if it could be proved that there is a distinct preference for them, it is noteworthy, considering the destruction that undoubtedly takes place, that though very variable they do not act as models or mimics, or form Müllerian combinations, either in India or Ceylon.

Failing the butterfly-eaters, what evidence is there that the birds of group 2, and group 3, show preference in their more or less desultory attacks? There is no doubt that those experimented on showed none, and that they took no notice of butterflies unless they were mutilated and rendered easy of capture. I should much wish to see further experiments on wild birds of these two groups undertaken, but if the butterfly-eaters do not conduce to mimicry, it is doubtful to my mind if the partial feeders would do so.

In the present state of our knowledge it is difficult to say what is or what is not an unpalatable genus, and the position is further complicated by the proposition that unpalatable species are killed in numbers sufficient to produce a special form of mimicry. It is unfortunate that theoretical considerations rather than observations and experiments in the field have hitherto preponderated in this matter. It seems to me that the terms palatable and unpalatable are not justified at present. 


\section{The Miillerian Theory.}

The supporters of the Müllerian theory hold the view that it is chiefly by the attacks of the young inexperienced birds that this form of mimicry is produced. Professor Poulton puts the case as follows:- " The Müllerian theory presupposes that only young birds test the palatability of a few members of each convergent group in their locality and henceforward, except when driven by hunger, avoid all the members, so that the recent tendency to explain so many of the resemblances on Muillerian rather than on Batesian lines is in harmony with the conclusion that the members of such groups are not greatly attacked by adult birds." (Essays on Evolution, p. 270.)

I have already expressed the opinion that it is unlikely that young birds, except those in group 1, indulge in tasting experiments on butterflies, but as I am quite willing to admit that such an opinion may be founded on insufficient data, and as I was unable to find the necessary evidence required by the Muillerian theory, I approached the subject by another line of investigation, which depends on the time of the nesting of the birds and the broods of the butterflies.

The birds breed once a year, not twice as is the case in Mauritius. They begin in March or April, sometimes early in May, according to the season. When the March or April rains known as the little monsoon bring out a large increase of insect life, the birds immediately begin nesting, and the young birds are off the nest and begin to forage for themselves in May, June or early July. The average life of an insectivorous bird is probably not more than four or five years, and we may assume that tasting experiments gradually grow fewer in number and are completed when the bird is about six months old, i.e. about the month of October.

In estimating the number of broods of butterflies in the year, which vary much according to the species, I will direct attention to two of the more striking cases of inimicry, that of the Euplœas, forming a Müllerian combination, and Papilio polytes with its trimorphic female mimicking $P$. aristolochice and $P$. (Menelaides) hector. They may be taken together. In January, February and March, that is to say in the dry weather ( $\mathrm{I}$ am speaking more particularly of the plains), there is a very small but continuous series of broods which depend on the weather for their development. If it is very dry, the eggs, larvæ or pupæ, as the case may be, lie dormant, but with favourable meteorological conditions such as a shower of rain, the eggs hatch, the larva shake off their lethargy and feed, or the butterfly emerges. Mr. Mackwood informed me that on March 24, 1908, in his garden at Colombo, eggs, larvæ and pupæ of Euploca core could be found together on the same tree. The majority of the pupæ do not, however, hatch out but remain quiescent until the April rains, when there is an astonishing outburst of butterfly and other insect life. With the onset of the south-west monsoon at the end of May or beginning 
of June, the broods become larger in numbers and more frequent, and this goes on until the end of August or beginning of September, when there is a further spell of dry weather similar to but not so pronounced as that in the early part of the year, when the broods again become smaller and less frequent, but at the same time produce the individuals which take part in the migratory flights of the monsoon in November and December.

Strictly speaking, $P$. hector and $P$. aristolochice, though following the above sequence of events, do not usually form part of the flights, but they are nevertheless at their maximum at this time; the Euploeas and Polytes undoubtedly do so. We have now to judge what influence the inexperienced young birds off the nest in May, and their experiments concluded in October, can have on these species. A butterfly the size of Euploca core pairs during its first flight, if we may judge by the cabinet condition of those ovipositing, and begins to lay its eggs three days afterwards. The usual number is about two hundred and fifty, which are deposited according to the weather in about ten days ( $I$ have known one hundred eggs laid in five days). What becomes of the parent after this? Whether she dies a natural death or becomes the victim of a tasting experiment is immaterial, her time of danger is a brief fortnight. As the females are less in evidence than the males, fewer of them would be captured, especially if we agree with Professor Poulton's opinion that the Müllerian theory presupposes that only young birds test the palatability of a few members of each convergent group in their locality. To bring to such perfection the cases of mimicry I have selected, we must assume that such a victim would be one having less converging characteristics than the others; and it must also be borne in mind that unless she is killed within three days of her emergence, she will have laid a certain number of eggs which will produce butterflies similar to herself. It is difficult to understand how the broods of butterflies, numbering some thousands of individuals, born between October and the following nesting season, would be in any way affected except in the very smallest manner. No doubt Nature is infinitely slow in her methods, and we have no reason to suppose that these cases of mimicry have been produced, otherwise than by a very lengthy process of weeding out; but even if we grant this, there is a still greater difficulty in the case of Hypolimnas misippus, the well known mimic of Danais chrysippus. In Ceylon the former appears on the wing in October, when as I have said tasting experiments are over. It remains on the wing until the end of the year, when it disappears until the following autumn. There are so far as I can see only two ways of getting over this difficulty-either by assuming that the inherited tendency to produce this form of mimicry has become so fixed that the withdrawal of the factor that produced it is immaterial, though there is no reason for this supposition, or that there is a more or less constant influx of the species from India. There is very little doubt that a certain number of Ceylon butterflies in their annual migratory flights 
find their way to India, but I can find no evidence of a reverse condition of things, and one can scarcely credit that the few chance stragglers which possibly find their way across the sea could keep up this perfection of mimicry in the south of the island. The supposition that the sudden appearance of a previously unknown species would produce further tasting experiments will not hold good in this case, as the mimic so closely resembles its model D. chrysippus, which is on the wing all the year round.

\section{Experiments on Young Birds in Confinement.}

I am extremely doubtful as to any real value accruing from experiments on caged birds, whether nestlings or adult. No one, I imagine, believes that all butterflies taste alike: no doubt some are more tasty than others, and caged birds fed upon butterflies even with other insect food would no doubt learn in time to distinguish the different kinds; but this procedure to my mind begs the question, as it assumes that butterflies are an ordinary article of food in the wild state, a proposition regarding which the evidence here brought forward does not altogether support. The case is different with Coleoptera, Hemiptera, Diptera and the like, which are known to be the staple food of birds. Lloyd Morgan's carefully conducted experiments leave no doubt that certain species of birds, probably all, have very little instinct as to what is good, and what not, and that they learn by imitation and tasting experiments. My observations lead me to believe that the former is very important. I briefly epitomize my own conclusions.

1. Young birds probably learn at first in a general way what is their natural provender by what is brought to them in the nest.

2. That this is further developed when they have left the nest but are too weak to accompany the parents when they are foraging for food.

3. That when they accompany the parents, as they do for a longer or shorter time according to the species, they notice the insects caught and attempt to capture them themselves.

4. When they are left to shift for themselves they carry on what they have learnt, and during this time they undertake tasting experiments, but with the exception of the birds in group 1, those on butterfies are few in number; first, because they have rarely or never had butterflies brought to them in the nest; secondly, because they have very rarely seen their parents catching them, and so neglect them; thirdly, because they have considerable difficulty in catching them, and the process of getting rid of the wings is tedious and lengthy and the morsel fluffy, and possibly not always agreeable. If these observations are confirmed by further experience, they would account for the fact that attacks on butterflies are less frequent than those on other insects. 


\section{Instances of Imitation by Young Crows.}

July, 1910. I saw an old crow and two young ones on the Rifle Green this morning; one of the youngsters had hold of a bone with a piece of gristle attached to it. It was so firmly adherent that the bird could not detach it as the bone constantly moved with the bird's efforts, and eventually it gave up. Then the old bird, which had been standing by all the time, went to the bone, put its foot on it, thereby gaining a purchase, and tore off the gristle without difficulty; the young bird after two or three attempts did the same.

September, 1910. An old crow had a piece of hard boiled potato off which it was picking pieces and giving them to a full-fledged young one close by. A goodly number of detached pieces lay on the ground and attracted the attention of some other crows, which flew down and began picking them up ; seeing this the youngster did likewise, though it made no attempt to do so before their arrival.

\section{Seasonal Dimorphism-Cryptic Defence.}

I should not conclude this study of mimicry without discussing that form of it which is known as "cryptic defence," and especially that which is so noticeable in the seasonal changes of so many tropical butterflies.

It is commonly believed to have been produced by natural selection acting through the medium of insectivorous foes, the more exact and perfect imitations found in the dry season being due to the paucity of insect life at that time of the year, which produces a greater keenness in pursuit and a greater struggle for existence. The argument has been put forward in full by Professor Poulton in his 'Essays on Evolution,' page 203.

I hope in the near future to deal more exhaustively with this subject, but at present will only direct attention to two species occurring in these islands, a study of which does not favour the usually accepted views. The contention for the production of the dry season form rests upon the premiss that " the dry season is a time of far greater pressure than the wet"; for although the enemies of insects are fewer, the insects themselves are proportionately even more reduced, and "the light thrown by recent investigation leads us confidently to believe that the differences between the seasonal forms - hitherto devoid of interpretationhave a meaning and a value in the struggle for existence and came into being under the sway of natural selection" (Poulton).

Though it is probably correct to say that in countries such as S. Africa and India, which have a continental climate, the seasons are such as to produce a wealth or poverty of insect life, it is decidedly incorrect to assume the same with regard to the islands we have been investigating. There is no doubt that at no season of the year is there in any of them a paucity of insect life, and at 
no time would an insectivorous bird, or reptile, find any difficulty in procuring its daily sustenance.

Bourbon and Mauritius are very largely under sugar cultivation, and this necessitates constant manuring of the fields, with a consequent abundance or superabundance of flies of all sorts throughout the year. The rainfall, though greater in the wet season, is not infrequent during the dry season, and this also favours insect life; and if we add to this the consideration of the practical absence of butterfly-eating birds and reptiles, we can estimate the difficulty of believing that these changes are the outcome of natural selection in these two islands.

In Ceylon Mr. E. Ernest Green, who has lived thirty years in the island and who knows every part of it, writes as follows :-

"Though insects are more abundant at certain seasons, I have never experienced any part of Ceylon where there was anything approaching a dearth of them. I know that I am always busy pinning and setting throughout the year.

"I sometimes wish that there was a short dead season, when one could devote oneself to other work without being distracted by the constant accumulation of material.

"I doubt if Melanitis is ever subject to much worry from birds. It lives in the shade and never moves during the daytime, unless flushed by some big animal. I am now receiving (16.8.10) both dry and wet season forms of $M$. tambra from Kandy."

An allied species Melanitis leda occurs also in Bourbon and Mauritius, and it is to be remarked that the dry season forms begin to appear before the advent of the dry season, that is to say before any form of stress would tend to make itself felt.

In explanation, it may be suggested that the butterfly was introduced from the locality where natural selection produced these changes and that it is simply carrying on an inherited tendency. That it is an introduced species is highly probable, but it has been known to entomologists in Bourbon and Mauritius for at least sixty years, and it differs in no way now than in the time of Boisduval. It is difficult to believe that the factor which produced this cryptic defence being removed and no longer required would not have led to some other form of colouring, or a return to that ancestral type from which these forms were evolved. The above remarks apply equally to Mycalesis narcissus, Precis rhadama (introduced 1858), and Terias floricola, and I have made a further study of Terias hecabe in Ceylon. It is very frequently the case that the wet form continues to appear well into the dry weather and vice versa, but to a less extent; this has been remarked on frequently, but so far as I know no exact observations have been made. In Colombo there was no rain from November 19th till December 10th, 1908, thence to January 6 th, $1909, \cdot 70$ of an inch, but of this no less than 57 fell on one day (Dec. 19th); such an absence of rain in a tropical country at once causes a general drying up of vegetation and the assumption of dry weather conditions. At weekly intervals I captured all the Terias I could, which were 
accustomed to breed on a hedge of Madras thorn in an isolated position in my garden; the results of such counts showed 73 wet forms, 1 intermediate, and 19 dry, and it was not until January 28th that the wet forms were entirely replaced.

The butterfly takes exactly a fortnight to pass from larva to imago, and thus we have approximately three or four broods of wet season forms produced under dry season conditions. We must assume that as the butterfly is seasonally dimorphic it stands in need of protection, yet so far as I could ascertain the wet forms suffered no diminution though exposed to what were, or should have been, adverse circumstances.

The butterflies rested during the night and in cloudy weather on the under surfaces of the leaves of Vinctasp.?, a small flowering shrub with pink flowers and small oval green or frequently yellow faded leaves. It often collected gregariously, two or even three being on the same leaf and perhaps ten on the same plant. The position was an admirable one for protection from the wet, and also from small predatory foes which seldom look upwards when hunting for prey. The appearance of the plant is the same throughout the year, and the butterfly derived no advantage from its change from one seasonal form to the other.

The following experiment makes me still further doubtful of these effects being due to natural selection.

If we take the pupa of a somewhat similarly coloured butterfly which is not seasonally dimorphic, such as Papilio demodocus or Papilio demoleus, and expose it to a hot dry temperature, we can produce an insect with much of the yellow on the under surface replaced by red. I am almost persuaded that these rusty red spots are a vestige of a character at one time common to certain Pierines and Papilionines which is more or less reproduced by heat and dryness, if of sufficient duration and intensity under natural conditions in the Pierines, but in the Papilionines only under artificial stimulation of a like but exaggerated character.

\section{Conclusions.}

1. It has been shown that in Bourbon and Mauritius there are no butterfly-eating birds or reptiles; so that the cases of mimicry occurring there cannot be due to their influence.

2. In Ceylon it has been conclusively shown that the butterflyeating reptiles are impartial feeders.

3 . That a trained observer can distinguish the majority of these mimetic butterflies at a distance of about twenty or thirty feet and frequently at the same number of yards ; and this being so, it is certain that a bird which has to depend for its existence on its powers of observation, could after a few failures be able to discriminate them at the same and probably at a considerable greater distance.

4. That Drongos feed largely upon Euploeas, and this being so, 
a Papilio mimicking them obtains no protection in the vicinity of these birds.

5. There is no bird in Ceylon known to eat butterflies that distinctly discriminates as an adult between one species of butterfly and another.

6. It has been shown that there is a great destruction of butterfly life in the dry zone, and that here, if anywhere, Müllerian or Batesian mimicry might be induced, but the destroyers are largely migratory and their attacks are not selective.

7. That the number of broods of butterflies which occur between the termination of tasting experiments in one year and the commencement of them in the next is so great that any influence which could be wrought by such is almost inappreciable.

8. The little evidence available shows that young Ceylon birds imitate their parents in their choice of food ; but as regards butterflies, the fact that there is no discrimination shown by adults leads one to conclude either that few or no tasting experiments were undertaken in youth, or, what is more probable, that their taste with regard to them is indifferent.

9. It is questionable, and so far as an accurate knowledge of one species goes it is definitely shown, that that form of mimicry represented by wet and dry season forms (cryptic defence) is not produced for the protection of the species, inasmuch as many (four) succeeding broods of the wet weather form may be found under dry season conditions without detriment to the species.

34. The Distribution of the Avian Genus Megapodius in the Pacific Islands. By J. J. Lister, M.A., F.R.S., F.L.S., F.Z.S.

[Received and Read May 9, 1911.]

(Text-figure 166.)

The Megapodiidæ or Mound Builders are, as is well known, large birds, with comparatively feeble powers of flight, constituting a family of the order Gallinæ. They are distributed over the islands of the East Indian Archipelago and Western Pacific, from the Philippines and Borneo to the New Hebrides, and are found in several parts of the continent of Australia. Four outlying species of the genus Megapodius are found in the Nicobar, the Pelew, and the Marianne Islands, and, far out in the Pacific, on the little island of Niuafou, belonging to the Tongan group.

As we cannot suppose that the birds found in these outlying islands, remote from the other species, can have flown across the intervening tracts of ocean, we are presented with the problem: How did they reach these islands?

The solution to which M. Oustalet gives his adhesion, in his Proc. Zool. Soc.-1911, No. LII. 


\section{$2 \mathrm{BHL}$ Biodiversity Heritage Library}

Manders, Neville. 1911. "An Investigation into the Validity of. Müllerian and other forms of Mimicry, with special reference to the Islands of Bourbon, Mauritius, and Ceylon." Proceedings of the Zoological Society of London 1911, 696-749. https://doi.org/10.1111/j.1096-3642.1911.tb01955.x.

View This Item Online: https://www.biodiversitylibrary.org/item/98513

DOI: https://doi.org/10.1111/j.1096-3642.1911.tb01955.x

Permalink: https://www.biodiversitylibrary.org/partpdf/72315

\section{Holding Institution}

Smithsonian Libraries

\section{Sponsored by}

Biodiversity Heritage Library

\section{Copyright \& Reuse}

Copyright Status: Public domain. The BHL considers that this work is no longer under copyright protection.

This document was created from content at the Biodiversity Heritage Library, the world's largest open access digital library for biodiversity literature and archives. Visit BHL at https://www.biodiversitylibrary.org. 